\title{
RKIP: A Key Regulator in Tumor Metastasis Initiation and Resistance to Apoptosis: Therapeutic Targeting and Impact
}

\author{
Apostolos Zaravinos ${ }^{1,2}$ (D) Benjamin Bonavida ${ }^{3}$, Ekaterini Chatzaki ${ }^{4}$ and Stavroula Baritaki ${ }^{5, *}$ \\ 1 Department of Life Sciences, School of Sciences, European University Cyprus, 2404 Nicosia, Cyprus; \\ a.zaravinos@euc.ac.cy \\ 2 Centre for Risk and Decision Sciences (CERIDES), 2404 Nicosia, Cyprus \\ 3 Department of Microbiology, Immunology, and Molecular Genetics, David Geffen School of Medicine, \\ University of California Los Angeles, Los Angeles, CA 90095, USA; bbonavida@mednet.ucla.edu \\ 4 Laboratory of Pharmacology, Medical School, Democritus University of Thrace, \\ 68100 Alexandroupolis, Greece; achatzak@med.duth.gr \\ 5 Division of Surgical Oncology, School of Medicine, University of Crete, Heraklion, 71500 Crete, Greece \\ * Correspondence: vbaritak@gmail.com; Tel.: +30-2810-394727
}

Received: 20 July 2018; Accepted: 18 August 2018; Published: 24 August 2018

\begin{abstract}
RAF-kinase inhibitor protein (RKIP) is a well-established tumor suppressor that is frequently downregulated in a plethora of solid and hematological malignancies. RKIP exerts antimetastatic and pro-apoptotic properties in cancer cells, via modulation of signaling pathways and gene products involved in tumor survival and spread. Here we review the contribution of RKIP in the regulation of early metastatic steps such as epithelial-mesenchymal transition (EMT), migration, and invasion, as well as in tumor sensitivity to conventional therapeutics and immuno-mediated cytotoxicity. We further provide updated justification for targeting RKIP as a strategy to overcome tumor chemo/immuno-resistance and suppress metastasis, through the use of agents able to modulate RKIP expression in cancer cells.
\end{abstract}

Keywords: RKIP; cancer; resistance; metastasis; EMT; therapy

\section{Introduction}

The RAF-kinase inhibitor protein [RKIP or Phosphatidylethanolamine-binding protein-1 (PEBP1)] has been critically involved in the regulation of distinct biological processes, through interactions with several signaling cascades, such as the mitogen-activated protein kinase (MAPK), nuclear factor kappa-light-chain-enhancer of activated B cells (NF-kB), G protein-coupled receptors (GPCR) and glycogen synthase kinase $\beta \beta$ (GSK3 $\beta$ ) pathways [1-7]. The reduction or loss of RKIP expression has been associated with the initiation and progression of multiple diseases, including cancer.

In numerous human cancers, RKIP was shown to act as an endogenous onco-suppressing protein affecting negatively tumor cell survival, proliferation, and metastasis [8]. The most well-reported role of RKIP is in the metastasis suppression [9-15]. Metastasis comprises of multiple steps, including the epithelial-to-mesenchymal transition (EMT), cellular migration, invasion, intravasation into blood or lymph vessels, extravasation from circulatory vessels, and tumor cell colonization at new tissue sites [16]. Each metastatic step encompasses intricate cell-cell interactions and signaling pathways. As a metastasis suppressor, RKIP impedes different stages of the aforementioned processes and its high level of expression is predictive of a better clinical outcome [9,14,17-21].

RKIP overexpression is further reported to reverse tumor chemo/immune/radio-resistance and support anticancer host immunosurveillance [22]. We and others have shown that cancer cells acquire 
therapeutic resistance through constitutive activation of multiple survival pathways that help them to evade apoptosis [23-34].

The main goal of this review is to update the vital impact of the RKIP expression levels in cancer cells on their sensitivity to cytotoxic therapies and on their metastatic potential. Accordingly, we mainly discuss the regulatory role of RKIP on multiple signaling modules reported so far to be involved in metastasis initiation and therapeutic resistance in various cancer types. We also discuss the most recent advances on the prognostic and therapeutic applications of RKIP expression levels in cancer.

\section{RKIP Expression Patterns across Different Cancer Types}

RKIP has been identified as an important protein in various cancer types, including those of prostate, melanoma, colorectal, liver, breast, urinary bladder, nasopharyngeal carcinoma, skin, lung and others [17,35-47]. Several studies have shown that RKIP exhibits low expression levels in various cancers and it is often absent in metastasis $[8,9,17,19,43,45,48-60]$. RKIP loss has been suggested to result by hypermethylation of its promoter [41].

Here, for instance, we measured RKIP mRNA expression across 37 different cancer types, using data from The Cancer Genome Atlas (TCGA) platform (https://cancergenome.nih.gov/), corroborating its downregulation in the majority of them compared to the normal tissues. Our analysis shows that RKIP exhibits its highest levels in adrenocortical carcinoma (ACC), liver hepatocellular carcinoma (LIHC), and thyroid carcinoma (THCA), and its lowest expression was detected in acute myeloid leukemia (LAML), esophageal carcinoma (ESCA), and stomach and esophageal carcinomas (STES) (Figure 1).

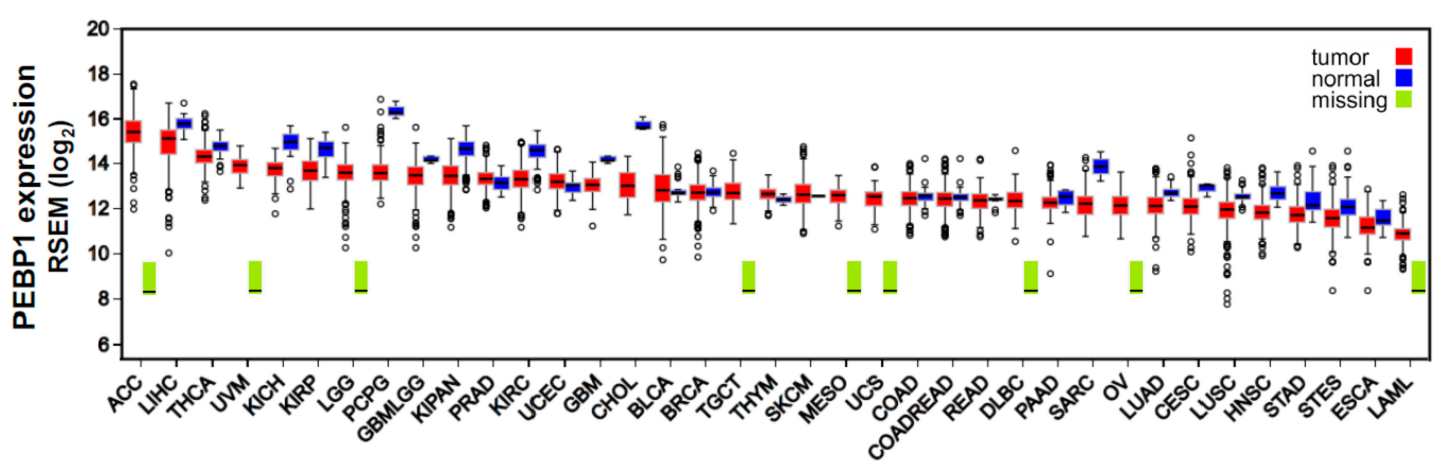

Figure 1. RKIP (PEBP1) expression across 37 TCGA cancers and their corresponding normal tissue. RKIP is downregulated in the majority of the different cancer types compared to the normal tissues. RNA-seq data quantification was performed using RSEM [61] following $\log _{2}$ transformation. Tumor sample number, ranges in the values of RKIP mRNA expression levels, and differential fold change between each tumor type and the corresponding normal tissue is presented in Table S1. Abbreviations: AAC, adrenocortical carcinoma; LIHC, liver hepatocellular carcinoma; THCA, thyroid carcinoma; UVM, uveal melanoma; KICH, kidney chromophobe carcinoma; KIRP, kidney renal papillary cell carcinoma; LGG, brain lower-grade glioma; PCPG, pheochromocytoma and paraganglioma; GBMLGG, glioma; KIPAN, Pan-kidney cohort (KICH+KIRC+KIRP); PRAD, prostate adenocarcinoma; KIRC, kidney renal clear cell carcinoma; UCEC, uterine corpus endometrial carcinoma; GBM, glioblastoma multiforme; $\mathrm{CHOL}$, cholangiocarcinoma; BLCA, bladder urothelial carcinoma; BRCA, breast invasive carcinoma; TGCT, testicular germ cell tumors; THYM, thymoma; SKCM, skin cutaneous melanoma; MESO, mesothelioma; UCS, uterine carcinosarcoma; COAD, colon adenocarcinoma; COADREAD, colorectal adenocarcinoma; READ, rectum adenocarcinoma; DLBCL, diffuse large B-cell lymphoma; PAAD, pancreatic adenocarcinoma; SARC, sarcoma; OV, ovarian serous cystadenocarcinoma; LUAD, lung adenocarcinoma; CESC, cervical squamous cell carcinoma and endocervical adenocarcinoma; LUSC, lung squamous cell carcinoma; HNSC, head and neck squamous cell carcinoma; STAD, stomach adenocarcinoma; STES, stomach and esophageal carcinoma; ESCA, esophageal carcinoma; LAML, acute myeloid leukemia. 


\section{RKIP Regulation}

RKIP expression is regulated at multiple levels (Figure 2). At the epigenetic level, the RKIP promoter is frequently found methylated in most cancers. We have reported enhancer of zeste homolog 2 (EZH2)-mediated H3-K27-me3 and H3-K9-me3 motifs in the RKIP promoter of prostate and breast cancer cell lines [62]. We have also used the Spearman's test to calculate the correlation between RKIP DNA methylation and mRNA expression profiles over 367 matched skin cutaneous melanoma samples, using "level 3" CpG site methylation and gene expression data extracted from the TCGA-SKCM dataset (https:/ / portal.gdc.cancer.gov/projects/TCGA-SKCM). We chose skin melanoma for this analysis due to the high number of metastatic cases provided by the TCGA platform. The CpG methylation and gene expression data were paired using the gene's Entrez ID number (5037). We found that RKIP mRNA expression is negatively correlated with the corresponding PEBP1 methylation probe (cg00091483) in position 118574757 of chr12 (correlation coefficient $=-0.412, p<0.0001, \mathrm{q}<0.0001$, mean expression $=12.59$ and mean $\mathrm{CpG}$ methylation $=0.057)$, providing further validation that $\mathrm{CpG}$ island hyper-methylation silences RKIP expression.

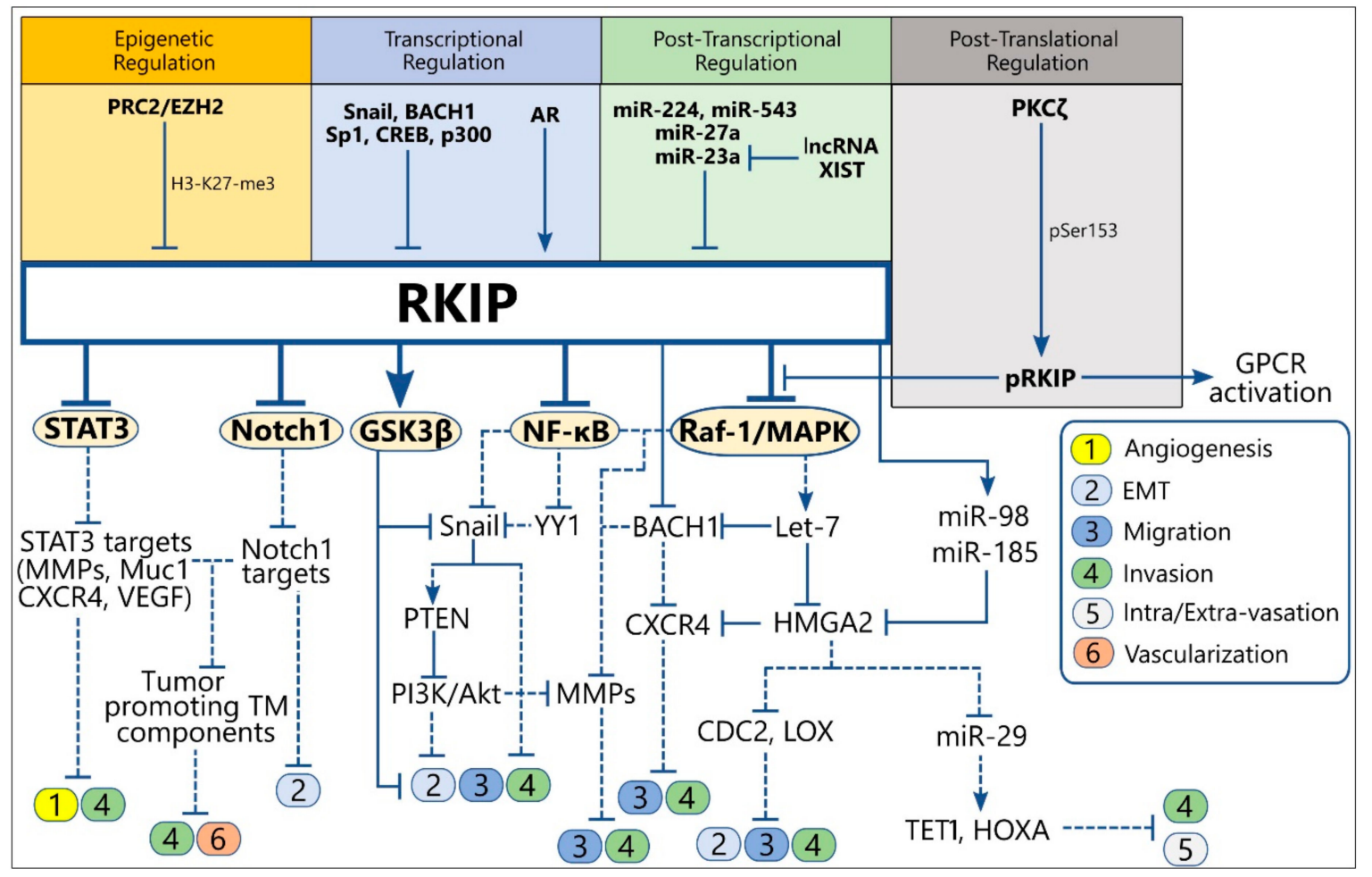

Figure 2. Schematic representation of the upstream regulators of RKIP expression (up) and the direct and indirect downstream RKIP targets involved in the regulation of metastasis initiation (down). Solid lines indicate the physiological function of each protein on the expression of downstream targets, while the dotted lines show the downstream effect(s) of the indicated protein after alteration of its levels by RKIP. Abbreviations: TM, Tumor microenvironment; EMT, Epithelial-to-Mesenchymal Transition; MMPs, Matrix Metalloproteinases; AR, Androgen Receptor; pRKIP, phosphorylated RKIP; PRC2, Polycomb Repressing Complex 2; EZH2, Enhancer of Zeste Homolog 2.

At the transcriptional level, direct binding of BTB domain and CNC homolog 1 (BACH1) and Snail1 (Snail) transcription factors to the RKIP promoter suppress RKIP transcription and expression [15,63]. Accordingly, the anticorrelated expression levels of RKIP, BACH1, and Snail are significant prognostic markers for metastasis-free survival of breast and prostate cancer patients [15,63]. RKIP promoter activity is also regulated by cis- and trans-acting elements within region -56 to +261 that responds to the transcription factors specificity protein 1 (Sp1), cyclic adenosine monophosphate 
(cAMP) response element-binding protein (CREB), and p300 [64]. Also, RKIP transcription is positively regulated via the direct binding of the androgen receptor (AR) to a putative androgen responsive element (ARE) within the RKIP promoter [65].

In various tumor models, RKIP mRNA has been shown to be targeted by miR-224 [66], miR-543 [67], miR-27a [68], and miR-23a [69], leading to its suppression. Contrarily, the long non-coding RNA (lncRNA) XIST stabilizes RKIP expression by suppressing miR-23a [70], while the IncRNA-GNAT-1 regulates the NF- $\mathrm{KB} /$ Snail cascade, an upstream inhibitor circuitry of RKIP expression [71]. The inhibitory NF-KB/YY1/Snail loop has also been reported to be targeted by forkhead box $\mathrm{O} 4$ (FOXO4), GATA binding factor, Sp1 and activation protein 4 (AP4), thus affecting indirectly RKIP expression [72,73].

At a post-translational level, a phosphorylation of RKIP at Serine 153 (pSer153-RKIP) by protein kinase $\mathrm{C} \zeta(\mathrm{PKC} \zeta$ ) has been found in several cancer types to account for loss of RKIP activity as a Raf-1 proto-oncogene, serine/threonine kinase/mitogen-activated protein kinase kinase/extracellular signal-regulated kinase (Raf/MEK/ERK) and GPCR inhibitor, through inhibition of $G$ protein-coupled receptor kinase 2(GRK2) [6,30,74-78]. In some cancers, the nuclear pSer153-RKIP levels significantly correlated with poor response to therapy and overall prognosis $[75,79]$. For example, RKIP overexpression in multiple myeloma mainly concerns its phosphorylated form (pSer153-RKIP), which impedes invasion and metastasis in preclinical animal models [36,80-82].

\section{Central Signaling Pathways Regulated by RKIP}

Under normal and pathophysiological conditions, including cancer, RKIP functions as a modulator of cellular growth, apoptosis, motility, genomic integrity, and therapeutic resistance [83]. RKIP critically interferes with the activation of basic upstream signaling pathways, which in turn govern the activity of individual downstream cascades essential for each of the above processes. Below, we focus on the central signaling cascades regulated by RKIP and discuss how their dysregulations in cancer confer to metastasis initiation and therapeutic resistance.

\subsection{GPCR and MAPK Signaling Inhibition by RKIP}

RKIP was first identified as an inhibitor of the Raf-1-stimulated MAPK signaling pathway (Raf-1/MEK/ERK) [3,8]. MAPK signaling is known to be hyperactivated in cancer cells and associated with metastasis initiation and therapeutic resistance [14,84]. RKIP functions as a competitive blocker of MEK phosphorylation by interrupting the Raf-1/MEK association, through direct binding to the Raf-1 kinase domain which prevents Ser338 and Tyr340/341 phosphorylation by PAK and Src Kinases, needed for Raf-1 activation [3,14,85]. Although RKIP may also associate with MEK and ERK, Raf-1 binding to RKIP and that of MEK are mutually exclusive [3,85]. Notably, B-Raf phosphorylation and activation are not directly affected by RKIP depletion, suggesting RKIP specificity for Raf-1 inhibition [7].

RKIP has been also reported to indirectly interfere with the activation status of upstream activators of Raf-1, such as GPCRs. The nature of this interference is mainly dictated by the phosphorylation status of RKIP. RKIP phosphorylation at Serine 153 (pS153) by PKC results in RKIP release from Raf- 1 and binding to GRK2, an endogenous inhibitor of GPCR activation $[6,86,87]$. Binding of pS153/RKIP to GRK2 is causing the dissociation of GRK2 from GPCR, allowing GPCR activation and phosphorylation of downstream targets, including Raf-1. Skinner et al. demonstrated the presence of a phosphorylation-triggered salt-bridge competition, or "theft" mechanism, that controls the association between pSer153-RKIP and GRK2 [88]. Therefore, RKIP binding switch from Raf-1 to GRK2 bridges MAPK and GPCR signaling and implies its role as an endogenous modulator of cell response to growth factor stimuli. 


\subsection{IKK/IkBa/NF- $\kappa B$ Signaling Inhibition by RKIP}

Constitutive activation of NF- $\mathrm{KB}$ is a hallmark not only in cancer initiation, progression, and metastasis, but also in tumor resistance to endogenous and exogenous apoptotic stimuli [89-91]. RKIP has been reported to negatively regulate NF-KB signaling, independently of MAPK, by antagonizing upstream signal transducers needed for NF- $\mathrm{KB}$ activation [1]. Yeung et al. first demonstrated physical interactions of RKIP with the upstream protein kinases of the NF- $\kappa B$ activating cascade, transforming growth factor beta-activated kinase 1 (TAK1) and NF- $\mathrm{kB}$-inducing kinase (NIK), as well as with their targeted downstream kinases of the IkappaB kinase (IKK) complex, IKK $\alpha$ and IKK $\beta$. The association of RKIP with NIK, TAK, IKK $\alpha$, and IKK $\beta$ abolishes their kinase activity, which results in elimination of IkappaB $\alpha(\mathrm{I} \kappa \mathrm{B} \alpha)$ phosphorylation and degradation, leading therefore to inhibition of the NF- $\mathrm{KB}$ activity [1].

\subsection{GSK3 $\beta$ Signaling by RKIP}

The RKIP/GSK3 $\beta$ axis was first reported by Al Mulla and colleagues to have a critical impact in sustaining GSK3 $\beta$ activity, as a suppressor of multiple oncogenic pathways, including those of Wnt and cyclin $\mathrm{D}$, known to be essential for tumor proliferation, progression, and metastasis [92]. RKIP can physically interact with GSK3 $\beta$, preventing GSK3 $\beta$ phosphorylation at the inhibitory T390 residue by $\mathrm{p} 38 \mathrm{MAPK}$, which is activated under oxidative stress augmented by RKIP depletion. RKIP dissociation from GSK3 $\beta$ de-represses GSK3 $\beta$-mediated inhibition of cyclin D stabilization and induction of $\beta$-catenin, Snail and Slug, thus promoting tumor cell proliferation and EMT [92].

\subsection{STAT3 Signaling Inhibition by RKIP}

Constitutive activation of signal transducer and activator of transcription 3 (STAT3) in human tumors is associated, among others, with promotion of tumor cell EMT, migration, invasion, angiogenesis, and resistance to apoptosis [93-96]. RKIP blocks STAT3 activation, by preventing its phosphorylation by upstream kinases [97]. RKIP overexpression in breast and prostate cancer cell lines was shown to inhibit cellular Src (c-Src) autophosphorylation and activation, as well as interleukin 6 (IL-6)-, janus kinase 1/2 (JAK1/2)-, and activated Raf-mediated STAT3 tyrosine and serine phosphorylation, needed for STAT3 activation. Inhibition of c-Src- and JAK1/2-induced STAT3 tyrosine phosphorylation is mediated through a physical interaction of RKIP with STAT3 that blocks c-Src and STAT3 association. Contrarily, the inhibition of Raf-mediated STAT3 serine phosphorylation is attained through RKIP-induced suppression of Raf-1 activity [97]. Accordingly, RKIP expression has been found to be inversely correlated with phosphorylated STAT3 (pSTAT3) levels in different tumor types $[75,76,98-100]$.

\section{Major RKIP-Induced Metastasis Suppressor Signaling Modules}

RKIP, as a master metastasis suppressor, exerts inhibitory functions at different steps of the metastatic process, including those that initiate metastasis such as angiogenesis, EMT, cell migration, and invasion [101,102]. RKIP targets signaling circuits that directly or indirectly regulate metastatic functions and which are mostly under the control of the central signaling pathways described above to be inhibited by RKIP. Therefore, the identification of RKIP acting sites throughout the metastatic process may reveal new targets for therapeutic intervention. Below, we present an updated overview of the cross-talks between RKIP and signaling modules involved in the regulation of the early metastatic events (Figure 2) (Table S1).

\subsection{RKIP-Targeted MicroRNAs and Downstream Pro-Metastatic Factors}

The microRNAs (miRNAs) have been suggested to play a vital role in almost all stages of tumor progression, through negative regulation of oncogenes and tumor suppressors [103]. One of the most well-characterized targets of RKIP is the let-7 family of microRNAs, which is known to suppress 
Ras-mediated MAPK activation and its subsequent effects on tumor invasion and metastasis [104]. Rosner and colleagues examined the underlying molecular mechanism of RKIP-induced let-7 upregulation in breast cancer metastasis models and showed that RKIP acts as a modulator of the Myc-Lin28-let-7 signaling cascade downstream of the Raf-1/MEK/ERK module $[105,106]$. RKIP, through MAPK inhibition, suppresses the activation of the ERK target Myc, which positively regulates the expression of let-7 inhibitor Lin28. As such, RKIP-mediated Myc inhibition downregulates Lin28 which in turn de-represses let-7, thus inhibiting tumor cell invasion and metastasis in vitro and in vivo $[107,108]$.

Further studies in breast cancer models revealed that RKIP may also prevent tumor cell invasion and metastasis indirectly, by negative regulation of critical prometastatic factors downstream of let-7, including high mobility group AT-hook 2 (HMGA2) and BACH1 [106,109]. HMGA2 is a chromatin remodeling factor that promotes EMT and invasion by upregulating Snail, Slug, and Twist $[14,18,110]$, while BACH1 is a transcription factor involved in bone metastasis of breast cancer by upregulating vital metastatic genes such as chemokine receptor type 4 (CXCR4) and matrix metalloproteinase 1 (MMP-1) [111]. Moreover, RKIP extends its indirect regulatory role downstream of HMGA2, in a number of additional let-7/HMGA2 targets involved in the metastatic process, as shown by gene and microRNA expression analyses performed in breast cancer cell lines [14]. The list of RKIP/let-7/HMGA2 targeted factors include, among others, syndecan (SDC2), miR-200b, lysine oxidase (LOX), miR-29, ten-eleven translocation 1 (TET1) and homeobox A-9 (HOXA9) [14,112]. In contrast to SDC2, miR-200b, LOX, and miR29 that positively regulate breast cancer initiation, EMT or invasion $[113,114]$, the expression of the TET1 demethylase and its downstream target HOXA9 have been shown to suppress invasion, intravasation, extravasation, and metastasis of triple-negative breast cancer (TNBC) cell lines in vitro and in vivo [14,112]. HMGA2 inhibition after ectopic RKIP induction in breast cancer cell lines resulted in induction of miR200b, which in turn downregulated its direct target LOX, thus leading to decreased tumor cell invasion and metastasis [109]. RKIP-mediated HMGA2 downregulation also directly inhibited the expression of the pro-metastatic factor SDC2 independently of miR-200b, resulting in suppression of tumor survival and metastasis [109]. Furthermore, HMGA2 depletion in breast cancer cells resulted in downregulation of miR-29 and induction of its target TET1, which in turn demethylates the promoter of the metastasis-suppressor HOXA9 and promotes its transcription [112]. RKIP has been further shown to potentiate HMGA2 inhibition and metastasis suppression independently of the Lin28/let-7 axis. RKIP overexpression in glioma cell lines was found to increase the expression of miR-98, which in turn inhibits its target gene HMGA2, resulting in decreased glioma cell invasion but without affecting tumor cell proliferation rates [115]. Concomitantly, in breast cancer models, RKIP induction was able to suppress tumor cell proliferation and invasion by upregulating miR-185, an upstream negative regulator of HMGA2 [116].

\subsection{RKIP-Mediated NF- $k B / Y Y 1 /$ Snail Circuity Inhibition}

$\mathrm{NF}-\mathrm{KB}$ signaling plays a critical role in tumor angiogenesis and the early metastatic events such as EMT. The list of NF- $\mathrm{KB}$-targeted genes involved in angiogenesis include basic fibroblast growth factor (b-FGF), $L L-8, M M P-2,-3$, and -9, while NF- $\mathrm{B} B$ inhibition abolishes vascular endothelial growth factor (VEGF) expression and suppresses angiogenesis $[89,117,118]$. NF- $\mathrm{KB}$ promotes EMT, cell migration and invasion not only by inducing the expression of MMPs, but also by regulating directly or indirectly the transcription of key EMT modulators, including the transcription factors Snail and Twist, as well as of cell adhesion molecules, such as selectins, integrins, and their ligands [119-122]. We and others have reported the role of drug-induced or ectopic RKIP expression in various cancer cell lines in the modulation of NF- $\mathrm{KB}$ signaling and its downstream targets that confer to the EMT phenotype and migratory and invasive properties of cancer cells [123-128]. For example, overexpression of RKIP in breast and pancreatic adenocarcinomas was able to suppress NF- $\mathrm{B} B-d e p e n d e n t$ tumor cell invasion through downregulation of MMPs $[124,125]$. Notably in melanoma RKIP was found to inhibit melanoma differentiation antigen-9 (MDA-9)/syntenin-mediated tumor migration and metastasis 
through physical association with MDA-9, that disturbs the assembly of stable c-Src/focal adhesion kinase (FAK) signaling complexes, which is essential for the activation of NF- $\mathrm{kB}$ and MMPs [129]. Treatment of prostate cancer cell lines with the proteasome inhibitor NPI-0052 or the nitric oxide donor DETA/NO was shown, in vitro and in vivo, to reverse tumor cell EMT, migration, and invasion through, at least, RKIP-mediated NF-KB signaling inhibition and consequent suppression of the EMT inducers, Snail, vimentin, N-catherin, and fibronectin, and E-cadherin upregulation [130,131]. RKIP, therefore, may participate in the indirect regulation of its transcriptional suppressor, Snail, via NF- $\mathrm{kB}$ inhibition [15,130-133]. Our preliminary findings have further identified an additional oncogene and NF- $\mathrm{kB}$ target, Yin Yang 1 (YY1), to play a vital role in prostate cancer metastasis, since YY1 silencing in metastatic prostate cancer cell lines was able to inhibit TGF $\beta$-induced EMT. YY1 involvement in regulating breast cancer metastasis has been previously reported [134]. RKIP overexpression inhibited YY1 mRNA and protein expressions, most likely via NF-kB inhibition [135]. Since Snail transcription is directly activated by YY1 [136], we can hypothesize that RKIP eliminates tumor EMT characteristics by acting as a negative regulator of the NF- $\mathrm{KB} / \mathrm{YY} 1 /$ Snail circuit [137]. These findings highlight the significance of NF- $\mathrm{KB} / \mathrm{YY} 1 /$ Snail circuitry targeting in cancer by various molecules with RKIP-inducing activities for reversal of EMT transformation $[74,123,138,139]$. Last, but not least, RKIP upregulation after Snail knockdown has also been shown to reduce the expression of colon cancer stem cell (CSC) markers leading to reversal of EMT [140].

\subsection{RKIP-Targeted STAT3 Inhibition}

Cytokine/growth factor-activated Src and STAT3 have been linked with promotion of EMT, migration, invasion, and angiogenesis in cancer cells [93-95,97,141,142], through induction of STAT3 downstream metastasis-associated proteins, including mucin 1 (Muc1), VEGF, and CXCR4, and by microtubule stabilization [143]. RKIP overexpression was reported to reverse STAT3-dependent prostate and breast cancer invasive and migratory properties, through a direct constitutive physical interaction with STAT3 that blocks c-Src and STAT3 association, needed for STAT3 activation [97]. These findings demonstrate that RKIP negates tumor angiogenesis, EMT and migration by interrupting the expression of Muc1, CXCR4, and VEGF [97]. A different study has indicated a physical interaction between RKIP and Annexin A7 (ANXA7), a suppressor of tumorigenesis and metastasis in prostate cancer. This interaction impairs the activation of ANXA7 GTPase by a small molecule SEC, which in turn leads to metastasis suppression via the AMPK/mammalian target of rapamycin complex 1 (mTORC1)/STAT3 signaling pathway [144]. The inhibitory role of RKIP on STAT3 signaling and the consequent effects on metastasis initiation in vitro and in vivo have been also validated by additional studies on other tumor models $[98,99,145]$.

\subsection{RKIP-Targeted Suppression of MMPs}

The overexpression of multiple MMPs is a hallmark in tumor invasion and metastasis [146]. In many cancers, the expression of MMPs such as $-1,-3,-10$, and -13 is negatively correlated with RKIP levels, suggesting that RKIP may constrain metastasis through inhibition of MMPs [147]. Interestingly, it has been proposed that the expression signature of RKIP and MMPs is better at predicting high metastatic risks in various cancers than the individual protein [102]. MMPs expression is induced by Raf/MEK/ERK, IKK/NF-KB, AKT serine/threonine kinase 1 (Akt) and STAT3 cascades, known to be inhibited by RKIP [93,148-150]. Along with the MMP1 inhibition by the RKIP/let-7/BACH1 axis in breast cancer cells, RKIP may exert inhibitory activities on MMPs expression through alternative signaling axes. For example, RKIP has been reported to inhibit local breast cancer invasion by antagonizing the transcriptional activation of MMP-13, mediated by the ERK2 signaling pathway and independently of the ERK2 downstream target activator protein 1 (AP-1) [102]. In contrast, MMP1 activation in the same tumor model was found to be RKIP- and AP-1-dependent. Erk2 but not Erk1 is known to induce EMT transformation in breast cancer cells [151]; however, the role of RKIP in inhibiting breast cancer cell EMT is still under investigation. Furthermore, the inhibition of glioma 
cell invasion and migration through RKIP-mediated suppression of MMP-2 and MMP-9, along with HMGA2, has also been reported by Lei et al. [152].

\subsection{Other Critical Interactions of RKIP with Metastasis Regulators}

Recent studies have provided evidence that RKIP is likely an upstream regulator of the Notch1 pathway in cancer cells [153]. The Notch pathway has been found aberrantly activated in many solid tumors, and its activation is functionally associated with different stages of tumor metastasis, including EMT [154-156]. Upon activation by ligand binding, Notch1 releases its intracellular domain (NICD), which subsequently translocate into the nucleus, where together with other transcription factors forms a transcriptional complex, responsible for the activation of EMT inducing genes, such as Slug and Snail [155-158]. Noh et al. showed that RKIP activity and levels in cervical and stomach cancer cell lines and tissues are inversely correlated with endogenous levels of NICD and that RKIP overexpression resulted in significant NICD reduction with subsequent inhibition of NICD-mediated expression of EMT markers, including vimentin, N-cadherin, and Snail. It was proposed that RKIP may attenuate Notch1 signaling through direct physical interaction; however, this interaction cannot affect the proteolytic release of NICD needed for Notch1 activation, thus suggesting that RKIP may play a distinct role in Notch1 activation during EMT and metastasis [153].

\subsection{RKIP-Targeted Tumor Microenvironment Components}

Recent findings suggest a strong involvement of metastasis regulators in modulating components of the tumor microenvironment and vice versa [159,160]. Besides cancer cells, the tumor microenvironment consists of different cell populations with pleiotropic functions in controlling tumor progression and metastasis. Among them, infiltrating immune cells, such as tumor-associated macrophages (TAMs) and myeloid cells, are known to add to the invasive phenotype of tumor cells [161].

In 2015, Rosner's and Yeung's groups reported, almost simultaneously, the role of RKIP in controlling macrophage infiltration in the breast cancer microenvironments, in vitro and in vivo [101,160]. RKIP expression in triple-negative breast tumors significantly reduced the number and metastatic potential of infiltrating TAMs. The underlying mechanism of TAM recruitment inhibition involved RKIP-mediated HMGA2 blockage which, in turn, induced a reduced expression of macrophage chemotactic factors, such as chemokine ligand 5 (CCL5), by cancer cells. The incompetence of the tumor microenvironment to be enriched by TAMs due to RKIP-mediated CCL5 reduction was translated into a decreased tumor cell invasiveness and secretion of pro-metastatic factors, including tumor necrosis factor receptor 2 (TNFR2) and progranulin (PRGN), by TAMs [160]. In conjunction with Frankenberger et al. findings, Datar et al. also reported that the inhibition of CCL5 by ectopic RKIP expression in an orthotopic breast cancer model was the cause of significant reductions observed in tumor vascularization, macrophage infiltration, and lung metastases [101]. Accordingly, the latter study established for the first time an inverse correlation between RKIP and CCL5 expression levels in clinical human breast cancer samples. Altogether, both studies identified RKIP as a novel negative regulator of the tumor microenvironment, at least by blocking the recruitment of pro-metastatic macrophages, through vital chemokine regulation.

Furthermore, RKIP expression was positively correlated with gene signatures involved in effective $\mathrm{T}$ cell responses during immunotherapy of metastatic melanoma with dendritic cell (DC) vaccination, but inversely correlated with genes associated with myeloid cell infiltration and inflammation such as STAT3, Notch1, and MAPK1 signaling members [162]. Similarly, in gastric cardiac adenocarcinoma tissues, negative RKIP expression coincided with lower $\mathrm{T}$ cell-mediated immune function in the tumor microenvironment and increased lymph node metastasis, possibly through NF-kB hyperactivity [163].

Summarizing, there is accumulating evidence supportive for the involvement of RKIP in the regulation of the tumor microenvironment, as it relates to the potency of specific immune cell infiltration and production of pro-metastatic factors. 


\section{RKIP as a Chemo-Immuno-Radio-Therapeutic Sensitizer in Cancer}

Cancer cells often develop therapeutic resistance along with increased metastatic potential, thus rendering the treatment less effective and the overall disease prognosis quite poor. In many cases, therapeutic resistance also coexists with increased likelihood of tumor cell escape host-immunosurveillance, such as immuno-mediated cytotoxicity. These coincidences may be attributed to dysfunction of signaling pathways that control tumor responses to both apoptotic and metastatic stimuli. Therefore, understanding the common underlying molecular mechanisms and identifying gene products able to simultaneously regulate the involved signaling cascades in cancer cells are important steps in addressing therapeutic resistance and metastasis management options in human malignancies.

We and others have implicated RKIP expression in regulating, along with the metastatic process, the tumor cell resistance to conventional chemotherapy, radiotherapy, and immuno-mediated cytotoxicity $[29,164]$. In the cancer models studied so far, RKIP functions as an apoptosis inducer, causing re-sensitization of resistant tumors to conventional therapeutic modalities and/or sensitivity to host immuno-surveillance. This is achieved via multiple interactions with signaling modules whose activation is known to confer to the resistant cancer cell phenotype (Figure 3) (Table S2). Interestingly, many of the implicated RKIP-modulated cascades are also involved in metastasis regulation, thus suggesting that RKIP may exert a dual function in metastasis and resistance by affecting common regulatory paths. Below, we summarize the most reported mechanisms of RKIP-mediated reversal of tumor therapeutic resistance.

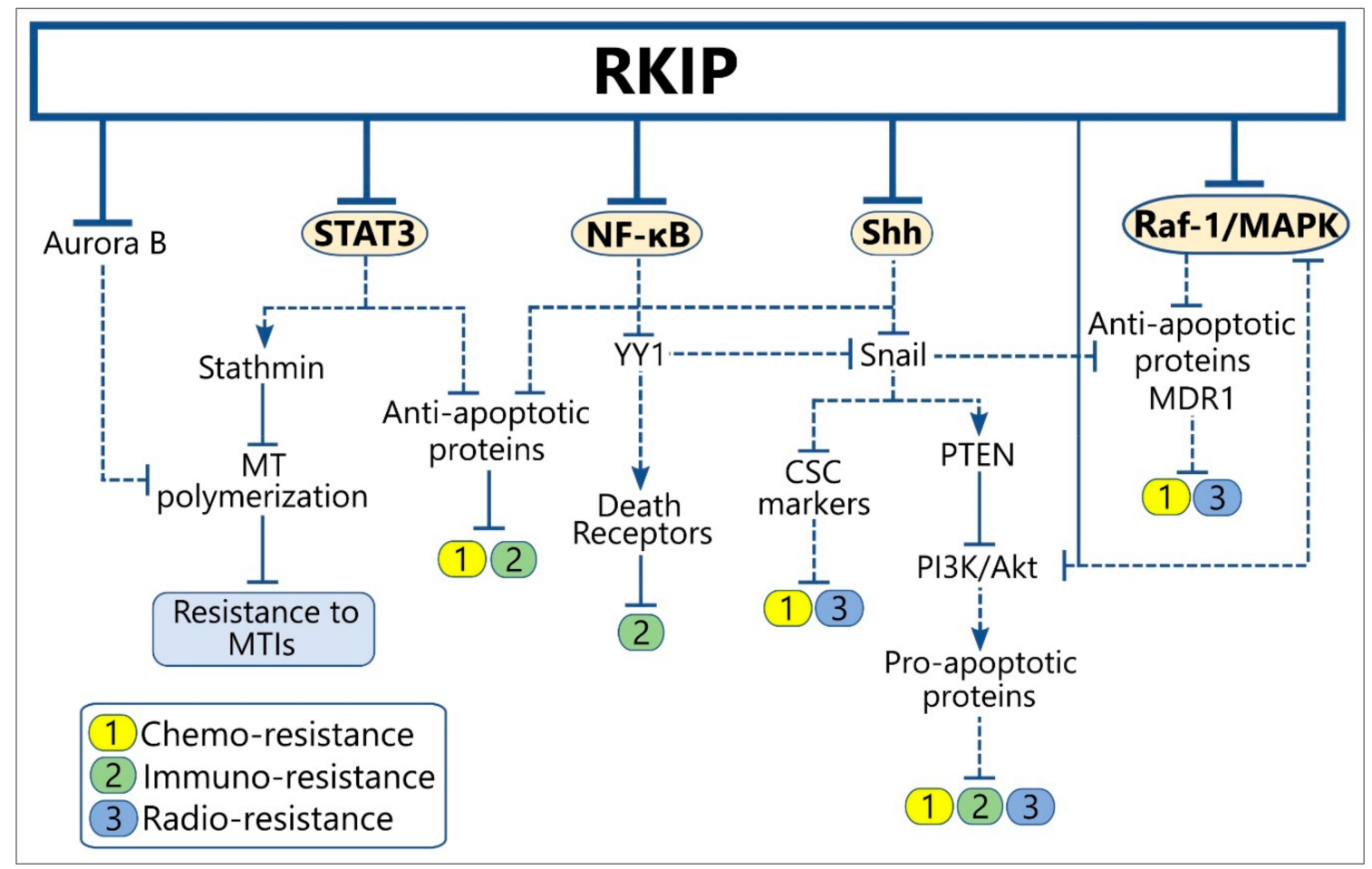

Figure 3. RKIP cross-talks with signaling modules regulating tumor resistance to therapy and host immune-surveillance. Solid lines indicate the physiological function of each protein on the expression of downstream targets, while the dotted lines show the downstream effect(s) of the indicated protein after alteration of its levels by RKIP. Abbreviations: CSCs, Cancer Stem Cells; MDR, Multi-Drug Resistance; MT, Microtubule; MTIs, Microtubule Inhibitors. 


\subsection{RKIP-Mediated Inhibition of NF- $\kappa B$ and Snail Signaling}

NF- $\mathrm{KB}$ activity promotes tumor resistance to conventional chemotherapy and immuno-mediated cytotoxicity mainly by inducing the expression of B-cell lymphoma 2 (Bcl-2)-related anti-apoptotic gene products, cellular FLICE (FADD-like IL-1 $\beta$-converting enzyme)-inhibitory protein (c-FLIP) and inhibitor of apoptosis proteins $1 / 2 \mathrm{c}-\mathrm{IAP} 1 / 2$ and X-linked inhibitor of apoptosis protein (XIAP), as well as by regulating death receptor expression $[90,91]$. We and others have reported that small molecules such as NPI-0052 and DETA/NO, or immunomodulating agents including $\alpha$ nti-CD20 and $\alpha$ nti-CD80 antibodies, are able to sensitize various resistant cancer cell lines to both chemo- and TNF-related apoptosis-inducing ligand (TRAIL)-mediated apoptosis, through NF-KB and Snail signaling inhibition and RKIP induction $[26,74,123,126,138,165,166]$. NF- $\kappa B$ constitutive activity has been also associated with adaptive tumor resistance to ionizing radiation [167]. The direct suppressive effects of RKIP ectopic induction or Snail silencing in the expression of the downstream anti-apoptotic proteins of the Bcl-2 family, as well as in the type II apoptotic pathway activation, support the opposing roles of RKIP and the NF-kB/Snail module in the regulation of tumor chemo/immuno-resistance $[26,126]$.

Furthermore, drug-induced Snail overexpression in colon cancer cell lines has been shown to corelate with elevated expression of CSC markers, such as CD133, Nanog, and Oct4, and increased chemoresistance. The above events were able to be reversed by Snail silencing and RKIP upregulation, suggesting that the Snail/RKIP loop is a critical regulatory component of CSC existence within the tumor, which in turn is associated with tumor chemoresistance [140]. Alongside, RKIP reduction enhanced non-small-cell lung cancer (NSCLC) radio-resistance via sonic hedgehog (Shh) signaling activation [168], which is known to accelerate CSC marker expression and sustain CSC self-renewal and functional properties partially through induction of Snail expression $[169,170]$. Altogether, the above findings demonstrate RKIP as a negative regulator of radio- and chemo-resistance by affecting the number and functions of CSCs within the tumor.

YY1 has been implicated, by us and others, in promoting therapeutic resistance and immunoescape in solid and hematological malignancies [22,171-174]. We have accumulating evidence demonstrating that $\mathrm{YY} 1$, as a downstream target of NF- $\mathrm{kB}$, can be modulated by RKIP-mediated NF-kB inhibition, thus abolishing its activity on cancer cell resistance [22,30,135]. RKIP-induced YY1 inhibition may further contribute to Snail suppression, given that $Y Y 1$ acts as a direct transcriptional activator of Snail $[30,74,136]$. YY1, therefore, may function as a linker between NF-kB and Snail activation statuses, that will critically affect the activity of downstream cell death apoptotic pathways [22,123]. Consequently, the modulatory ability of RKIP towards the NF-kB/YY1/Snail circuitry can be considered as one of the underlying mechanisms of RKIP-mediated inhibition of tumor chemo/immuno-resistance [22,30]. Accordingly, agents able to induce RKIP expression or to mimic RKIP function in promoting NF- $\mathrm{KB} / \mathrm{YY} 1 /$ Snail suppression are of therapeutic importance for the reversal of acquired therapeutic resistance, including photo-resistance [26,74,123,138,172,175-177].

\subsection{RKIP-Mediated Death Receptor Induction}

There is strong evidence for RKIP implication in the indirect regulation of death receptors (DR) expression, by inhibiting their transcriptional repression and, therefore, increasing cell sensitivity to immuno-mediated cytotoxicity. An underlying mechanism of DR induction by RKIP in cancer cells is through inhibition of the NF-KB/YY1 cascade. We and others have shown that YY1 acts as transcriptional repressor of DR5 and Fas receptors in different cell types $[173,178]$. The de-repression of death receptor transcription by RKIP-promoting drugs (NPI-0052, DETA/NO, etc.), or RKIP overexpression abrogates tumor resistance to TRAIL and Fas-ligand (FasL)-mediated apoptosis [26,31,34,74,80,139,179-185]. Indeed, YY1 levels have been found inversely correlated with DR5, Fas, and RKIP expressions in multiple cancer tissues $[30,73,186,187]$.

We have also shown that the sensitizing activity of immune-modulatory agents, such as the anti-CD20 monoclonal antibodies (mAbs) Rituximab, LFB-603, and BM-ca, on B-cell Non-Hodgkins lymphoma (B-NHL) cell lines resistant to TRAIL/FasL- and natural killer (NK)-induced apoptosis also 
involved Ab-mediated YY1 inhibition [74,183,188,189]. Given that all the above agents induced RKIP expression, and RKIP overexpression suppresses YY1, we can suggest that the tested agents enhance their sensitizing action to apoptotic death, through RKIP-mediated YY1 inhibition and death receptor upregulation. In addition, we cannot exclude, although never tested so far, that RKIP induction by anti-CD20 Abs may further interfere with the potency of antibody-dependent cell-mediated cytotoxicity (ADCC) and complement dependent cytotoxicity (CDC), known to be also mediated by therapeutic $\alpha$ nti-CD20 Abs.

\subsection{RKIP-Mediated MAPK and PI3K/AKT Signaling Inhibition}

The MAPK signaling dynamics influences tumor response to conventional chemotherapy, as demonstrated by a number of studies in multiple preclinical models of solid and hematological malignancies [24]. The underlying molecular mechanisms of resistance involve profound effects of the Raf/MEK/ERK pathway on the expression and activities of drug pumps and apoptosis-related proteins such as the multi-drug resistant- (MDR-1), Bad, Bim, Mcl-1, caspase 9, and Bcl-2, resulting in inhibition of drug-induced apoptosis [190-195]. These effects mainly occur at the transcriptional and post-translational levels, as the activation of Raf/MEK/ERK may induce the phosphorylation of transcription factors that bind to the promoters of MDR-1 and Bcl-2, thus stimulating their transcription. Raf/MEK/ERK activation may also promote the phosphorylation of the anti-apoptotic Mcl-1 protein and the pro-apoptotic Bim protein, resulting in the activation and proteasome degradation of the respective proteins [196-198]. Similarly, constitutive activation of the PI3K/Akt signaling in cancer cells has been also associated with apoptosis reduction, via several mechanisms [199].

In some cancer types, the MAPK- and/or PI3K/Akt-dependent radio-resistance and/or chemo-resistance has been reported to be promoted by RKIP reduction, via constitutive phosphorylation and activation of ERK and/or Akt [34,200-202]. Along with NF- $\mathrm{kB}$, downstream targets of both ERK and PI3K/Akt signaling are known to be implicated in the negative regulation of apoptosis induced by conventional chemotherapy or ionizing radiation [201,203-207]. Given that both pathways are activated by GPCR/Ras signaling and cross-talking at multiple levels [208-213], it is expected that the inhibitory function of RKIP on GPCR activation and Ras/Raf/MEK/ERK signaling may also affect Akt activity. Indeed, ectopic RKIP expression or upregulation by chemo/immune-modulatory agents, increased tumor chemo- and radio-sensitivity in vitro, by suppressing MAPK and/or PI3K activation [34,200,201].

Another proposed mechanism of Akt signaling inhibition is through RKIP-mediated modulation of the NF-kB/YY1/Snail/ phosphatase and tensin homolog (PTEN) circuitry, which can act independently of MAPK inhibition [175]. We have shown that RKIP induction in NHL cell lines by the LF-603 $\alpha$ nti-CD20 mAb co-exists with upregulation of the tumor suppressor phosphatase and tensin homologue (PTEN) and Snail/YY1 inhibition, resulting in tumor immune-sensitization [74]. As PTEN is an endogenous inhibitor of the PI3K/Akt signaling [214] and it is transcriptionally repressed by Snail [215], we suggest that RKIP-mediated NF-KB/YY1/Snail inhibition may trigger Akt inactivation by PTEN induction, leading to subsequent reversal of the resistant tumor phenotype.

\subsection{RKIP-Mediated Reversal of Tumor Resistance by STAT3 Inhibition}

There is substantial evidence demonstrating RKIP as a critical player in opposing the effects of pro-oncogenic STAT3 activation in cell survival and therapeutic resistance. Constitutive STAT3 activation in cancer cells has been associated with enhanced transcription of anti-apoptotic genes, thus increasing tumor resistance to apoptosis and promoting neoplastic progression [216,217]. RKIP overexpression has been reported by Yousuf et al. to reverse breast and prostate cancer resistance to microtubule inhibitors (MTIs) by inhibiting STAT3 activity in vitro and in vivo [97]. As an underlying mechanism, it was proposed the interruption of c-Src-STAT3 association by RKIP, that leads to insufficient STAT3-mediated inhibition of the microtubule-destabilizing protein Stathmin, which is needed for microtubule polymerization [143]. These findings can be explained by the recently 
reported role of RKIP in mediating microtubule dynamics in cancer cells by regulating mitotic spindle checkpoints via association with centrosomes and kinetochores through Aurora B kinase [4].

The significance of RKIP-mediated STAT3 regulation on tumor survival has been also highlighted by other studies. IL-6-mediated activation of STAT3 in colon cancer cell lines was shown to occur in conjunction with the phosphorylation (inactivation) of RKIP, leading to poor prognosis of colon cancer stage II patients. Cell treatment with oxaliplatin and camptothecin was able to block IL-6-mediated STAT3 activation and RKIP phosphorylation via the inhibition of STAT3/gp130 interaction [75].

\section{RKIP as a Prognostic Indicator and a Therapeutic Target}

\subsection{RKIP's Prognostic Value}

The involvement of RKIP in cancer progression and metastasis was suggested almost a decade ago [15]. Since then, several studies have evaluated RKIP as a prognostic factor for survival in different cancers and emerging evidence suggests its use as a therapeutic target $[9,19,218,219]$. The loss of RKIP is an independent indicator of poor prognosis in patients with digestive tract cancers, including esophageal, gastric, and colorectal cancer [220]. Low RKIP expression or its loss associates with the onset and development of gastric cancers and its ability to invade and metastasize [57,221], as well as with recurrence in esophageal squamous cell carcinoma (ESCC) [222], malignant progression in hepatic fibrosis [223], and poor survival in gastric cancer [224,225]. RKIP loss also serves as a predictive marker for the progression and metastasis of liver [226,227], kidney [228], breast [229], ovarian [230], and colorectal cancers [231], as well as pancreatic ductal adenocarcinoma (PDAC) [232]. Combined with its promoter's methylation, RKIP expression was further suggested as a biomarker of ESCC [233]. Phospho-RKIP was also reported as a predictive indicator of survival in lung cancer [234].

Furthermore, RKIP expression correlated negatively with disease-specific survival [235] in patients with colorectal and ductal breast cancers $[19,236]$. Furthermore, along with the expression of urokinase plasminogen activator receptor (uPAR), the proliferative index and tumor border configuration, RKIP expression was identified as a decisive classifier for the identification of colorectal tumors with vascular invasion [237-239]. Noteworthy, Shvartsur et al. constructed various possible cross-talks between RKIP (active/inactive) and the gene products underlying the mechanism of RKIP overexpression in multiple myeloma, aiming to use such molecular signatures for a more precise diagnosis/prognosis of the disease [80].

\subsection{RKIP-Inducing Agents}

Since RKIP is commonly downregulated in the majority of the human cancers, several drugs could potentially be used to upregulate its expression. These can be either synthetic drugs or natural agents, but treatment options also include specific proteins and microRNAs, as mentioned above [11].

The synthetic agents/drugs being used induce the interaction of RKIP with its partners in the MAPK and PKC pathways, and thus inhibit tumor progression, metastasis, and EMT [83]. Such drugs include rituximab [240], dihydroartemisinin [241], and didymin [242], all of which upregulate RKIP protein expression. Moreover, Shogaol, a constituent of ginger similar in chemical structure to gingerol, has been used to increase RKIP levels [243], as well as camptothecin and oxaloplatin, both of which inhibit RKIP phosphorylation [75]. Furthermore, we have shown that nitric oxide (NO) donors, such as DETA/NO, upregulate RKIP by inhibiting the NF- $\mathrm{kB} / \mathrm{YY} 1 /$ Snail regulatory circuitry resulting in tumor chemo-immuno-sensitization and inhibition of EMT and metastasis $[31,123,175]$. The potential therapeutic use of NO donors was also suggested in the treatment of patients with refractory cancers and in the prevention of the initiation of the metastatic cascade via EMT [123].

More recently, the regulation of RKIP using different natural agents is attracting interest. Its expression was significantly boosted in PDAC cells that were treated with epigallocatechin gallate (EGCG). EGCG management also impeded both the nuclear accumulation of NF-kB and functionally active ERK [125]. Furthermore, ginseng extract (Panaxquinquefolius L.) could reduce phospho-ERK1/2 
and -MEK1/2 levels and increase RKIP and pRaf-1 in breast carcinoma cells [244]. NPI-0052 is a natural proteasome inhibitor shown by us and others to induce RKIP via NF- $\mathrm{kB} /$ Snail inhibition, resulting in reversal of prostate cancer cell EMT, migration, invasion, and chemo/immune sensitization [26,130]. Apart from inhibiting NF- $\mathrm{kB}$, proteasome inhibitors restore RKIP levels by impeding proteasome degradation of the ubiquitinated protein in triple-negative breast cancer cells [245].

\section{Concluding Remarks}

It is clear that the pleiotropic activities of RKIP in cancer have evolved rapidly since its discovery in 1999. RKIP manifests inhibitory functions in central signaling pathways involved in the promotion of most tumor-related properties. RKIP low/absent expression in the majority of cancers underlies, among others, tumor response to apoptotic and metastatic stimuli. Suppression of tumor cell therapeutic resistance, angiogenesis and metastasis initiation and progression by RKIP emphasizes the potential of high RKIP levels in re-sensitizing resistant tumors and reducing the risk of aggressive tumors to metastasize. Therefore, it may be crucial to identify available modalities with RKIP-promoting activities, or develop new agents targeting RKIP overexpression, that can be used alone or in combination, to abolish the cancer-related properties listed above and resulting in novel successful therapeutic approaches for all cancers.

Supplementary Materials: The following are available online at http:/ /www.mdpi.com/2072-6694/10/9/287/s1, Table S1: Reported signaling modules whose modification by RKIP contributes to inhibition of metastasis initiation in various cancer types, Table S2: Reported signaling modules whose modification by RKIP contributes to inhibition of therapeutic resistance in various cancer types.

Funding: This research received no external funding.

Acknowledgments: We would like to thank Yuhao Wang for helping in the preparation of Figures 2 and 3.

Conflicts of Interest: The authors declare no conflict of interest.

\section{References}

1. Yeung, K.C.; Rose, D.W.; Dhillon, A.S.; Yaros, D.; Gustafsson, M.; Chatterjee, D.; McFerran, B.; Wyche, J.; Kolch, W.; Sedivy, J.M. Raf kinase inhibitor protein interacts with NF-kappaB-inducing kinase and TAK1 and inhibits NF-kappaB activation. Mol. Cell. Biol. 2001, 21, 7207-7217. [CrossRef] [PubMed]

2. Al-Mulla, F.; Bitar, M.S.; Taqi, Z.; Yeung, K.C. RKIP: Much more than Raf kinase inhibitory protein. J. Cell. Physiol. 2013, 228, 1688-1702. [CrossRef] [PubMed]

3. Yeung, K.; Seitz, T.; Li, S.; Janosch, P.; McFerran, B.; Kaiser, C.; Fee, F.; Katsanakis, K.D.; Rose, D.W.; Mischak, H.; et al. Suppression of Raf-1 kinase activity and MAP kinase signalling by RKIP. Nature 1999, 401, 173-177. [CrossRef] [PubMed]

4. Eves, E.M.; Shapiro, P.; Naik, K.; Klein, U.R.; Trakul, N.; Rosner, M.R. Raf kinase inhibitory protein regulates aurora B kinase and the spindle checkpoint. Mol. Cell 2006, 23, 561-574. [CrossRef] [PubMed]

5. Keller, E.T.; Fu, Z.; Brennan, M. The role of Raf kinase inhibitor protein (RKIP) in health and disease. Biochem. Pharmacol. 2004, 68, 1049-1053. [CrossRef] [PubMed]

6. Lorenz, K.; Lohse, M.J.; Quitterer, U. Protein kinase C switches the Raf kinase inhibitor from Raf-1 to GRK-2. Nature 2003, 426, 574-579. [CrossRef] [PubMed]

7. Trakul, N.; Menard, R.E.; Schade, G.R.; Qian, Z.; Rosner, M.R. Raf kinase inhibitory protein regulates Raf-1 but not B-Raf kinase activation. J. Biol. Chem. 2005, 280, 24931-24940. [CrossRef] [PubMed]

8. Escara-Wilke, J.; Yeung, K.; Keller, E.T. Raf kinase inhibitor protein (RKIP) in cancer. Cancer Metastasis Rev. 2012, 31, 615-620. [CrossRef] [PubMed]

9. Hagan, S.; Al-Mulla, F.; Mallon, E.; Oien, K.; Ferrier, R.; Gusterson, B.; García, J.J.C.; Kolch, W. Reduction of Raf-1 kinase inhibitor protein expression correlates with breast cancer metastasis. Clin. Cancer Res. 2005, 11, 7392-7397. [CrossRef] [PubMed]

10. Hao, C.; Wei, S.; Tong, Z.; Li, S.; Shi, Y.; Wang, X.; Zhu, Z. The effects of RKIP gene expression on the biological characteristics of human triple-negative breast cancer cells in vitro. Tumour Biol. 2012, 33, 1159-1167. [CrossRef] [PubMed] 
11. Farooqi, A.A.; Li, Y.; Sarkar, F.H. The biological complexity of RKIP signaling in human cancers. Exp. Mol. Med. 2015, 47, e185. [CrossRef] [PubMed]

12. Lorenz, K.; Schmid, E.; Deiss, K. RKIP: A governor of intracellular signaling. Crit. Rev. Oncog. 2014, 19, 489-496. [CrossRef] [PubMed]

13. Lamiman, K.; Keller, J.M.; Mizokami, A.; Zhang, J.; Keller, E.T. Survey of Raf kinase inhibitor protein (RKIP) in multiple cancer types. Crit. Rev. Oncog. 2014, 19, 455-468. [CrossRef] [PubMed]

14. Yesilkanal, A.E.; Rosner, M.R. Raf kinase inhibitory protein (RKIP) as a metastasis suppressor: Regulation of signaling networks in cancer. Crit. Rev. Oncog. 2014, 19, 447-454. [CrossRef] [PubMed]

15. Beach, S.; Tang, H.; Park, S.; Dhillon, A.S.; Keller, E.T.; Kolch, W.; Yeung, K.C. Snail is a repressor of RKIP transcription in metastatic prostate cancer cells. Oncogene 2008, 27, 2243-2248. [CrossRef] [PubMed]

16. Vanharanta, S.; Massagué, J. Origins of metastatic traits. Cancer Cell 2013, 24, 410-421. [CrossRef] [PubMed]

17. Fu, Z.; Smith, P.C.; Zhang, L.; Rubin, M.A.; Dunn, R.L.; Yao, Z.; Keller, E.T. Effects of raf kinase inhibitor protein expression on suppression of prostate cancer metastasis. J. Natl. Cancer Inst. 2003, 95, 878-889. [CrossRef] [PubMed]

18. Dangi-Garimella, S.; Yun, J.; Eves, E.M.; Newman, M.; Erkeland, S.J.; Hammond, S.M.; Minn, A.J.; Rosner, M.R. Raf kinase inhibitory protein suppresses a metastasis signalling cascade involving LIN28 and let-7. EMBO J. 2009, 28, 347-358. [CrossRef] [PubMed]

19. Al-Mulla, F.; Hagan, S.; Behbehani, A.I.; Bitar, M.S.; George, S.S.; Going, J.J.; García, J.J.C.; Scott, L.; Fyfe, N.; Murray, G.I.; et al. Raf kinase inhibitor protein expression in a survival analysis of colorectal cancer patients. J. Clin. Oncol. 2006, 24, 5672-5679. [CrossRef] [PubMed]

20. Keller, E.T.; Fu, Z.; Yeung, K.; Brennan, M. Raf kinase inhibitor protein: A prostate cancer metastasis suppressor gene. Cancer Lett. 2004, 207, 131-137. [CrossRef] [PubMed]

21. Minoo, P.; Zlobec, I.; Baker, K.; Tornillo, L.; Terracciano, L.; Jass, J.R.; Lugli, A. Loss of raf-1 kinase inhibitor protein expression is associated with tumor progression and metastasis in colorectal cancer. Am. J. Clin. Pathol. 2007, 127, 820-827. [CrossRef] [PubMed]

22. Bonavida, B.; Jazirehi, A.; Vega, M.I.; Huerta-Yepez, S.; Baritaki, S. Roles Each of Snail, Yin Yang 1 and RKIP in the Regulation of Tumor Cells Chemo-immuno-resistance to Apoptosis. For. Immunopathol. Dis. Therap. 2013, 4. [CrossRef] [PubMed]

23. Inoue, J.I.; Gohda, J.; Akiyama, T.; Semba, K. NF-kappaB activation in development and progression of cancer. Cancer Sci. 2007, 98, 268-274. [CrossRef] [PubMed]

24. McCubrey, J.A.; Steelman, L.S.; Chappell, W.H.; Abrams, S.L.; Wong, E.W.T.; Chang, F.; Lehmann, B.; Terrian, D.M.; Milella, M.; Tafuri, A.; et al. Roles of the Raf/MEK/ERK pathway in cell growth, malignant transformation and drug resistance. Biochim. Biophys. Acta 2007, 1773, 1263-1284. [CrossRef] [PubMed]

25. Vega, M.I.; Jazirehi, A.R.; Huerta-Yepez, S.; Bonavida, B. Rituximab-induced inhibition of YY1 and Bcl-xL expression in Ramos non-Hodgkin's lymphoma cell line via inhibition of NF-kappa B activity: Role of YY1 and Bcl-xL in Fas resistance and chemoresistance, respectively. J. Immunol. 2005, 175, 2174-2183. [CrossRef] [PubMed]

26. Baritaki, S.; Yeung, K.; Palladino, M.; Berenson, J.; Bonavida, B. Pivotal roles of snail inhibition and RKIP induction by the proteasome inhibitor NPI-0052 in tumor cell chemoimmunosensitization. Cancer Res. 2009, 69, 8376-8385. [CrossRef] [PubMed]

27. Schuierer, M.M.; Heilmeier, U.; Boettcher, A.; Ugocsai, P.; Bosserhoff, A.K.; Schmitz, G.; Langmann, T. Induction of Raf kinase inhibitor protein contributes to macrophage differentiation. Biochem. Biophys. Res. Commun. 2006, 342, 1083-1087. [CrossRef] [PubMed]

28. Tang, H.; Park, S.; Sun, S.C.; Trumbly, R.; Ren, G.; Tsung, E.; Yeung, K.C. RKIP inhibits NF-kappaB in cancer cells by regulating upstream signaling components of the IkappaB kinase complex. FEBS Lett. 2010, 584, 662-668. [CrossRef] [PubMed]

29. Chatterjee, D.; Bai, Y.; Wang, Z.; Beach, S.; Mott, S.; Roy, R.; Braastad, C.; Sun, Y.; Mukhopadhyay, A.; Aggarwal, B.B.; et al. RKIP sensitizes prostate and breast cancer cells to drug-induced apoptosis. J. Biol. Chem. 2004, 279, 17515-17523. [CrossRef] [PubMed]

30. Wottrich, S.; Kaufhold, S.; Chrysos, E.; Zoras, O.; Baritaki, S.; Bonavida, B. Inverse correlation between the metastasis suppressor RKIP and the metastasis inducer YY1: Contrasting roles in the regulation of chemo/immuno-resistance in cancer. Drug Resist. Updat. 2017, 30, 28-38. [CrossRef] [PubMed] 
31. Bonavida, B.; Garban, H. Nitric oxide-mediated sensitization of resistant tumor cells to apoptosis by chemo-immunotherapeutics. Redox Biol. 2015, 6, 486-494. [CrossRef] [PubMed]

32. Bonavida, B. RKIP-mediated chemo-immunosensitization of resistant cancer cells via disruption of the NF-kB/Snail/YY1/RKIP resistance-driver loop. Crit. Rev. Oncog. 2014, 19, 431-445. [CrossRef] [PubMed]

33. Huerta-Yepez, S.; Vega, M.; Jazirehi, A.; Garban, H.; Hongo, F.; Cheng, G.; Bonavida, B. Nitric oxide sensitizes prostate carcinoma cell lines to TRAIL-mediated apoptosis via inactivation of NF-kappa B and inhibition of Bcl-xl expression. Oncogene 2004, 23, 4993-5003. [CrossRef] [PubMed]

34. Jazirehi, A.R.; Vega, M.I.; Chatterjee, D.; Goodglick, L.; Bonavida, B. Inhibition of the Raf-MEK1/2-ERK1/2 signaling pathway, Bcl-xL down-regulation, and chemosensitization of non-Hodgkin's lymphoma B cells by Rituximab. Cancer Res. 2004, 64, 7117-7126. [CrossRef] [PubMed]

35. Li, H.Z.; Gao, Y.; Zhao, X.L.; Liu, Y.X.; Sun, B.C.; Yang, J.; Yao, Z. Effects of raf kinase inhibitor protein expression on metastasis and progression of human breast cancer. Mol. Cancer Res. 2009, 7, 832-840. [CrossRef] [PubMed]

36. Zaravinos, A.; Kanellou, P.; Baritaki, S.; Bonavida, B.; Spandidos, D.A. BRAF and RKIP are significantly decreased in cutaneous squamous cell carcinoma. Cell Cycle 2009, 8, 1402-1408. [CrossRef] [PubMed]

37. Xu, H.; Wang, X.; Shen, W.; Wang, L.; Shen, G.; Chen, M.; Zhou, L. The expression and significance of RKIP in lung squamous cell carcinoma tissues. Zhongguo Fei Ai Za Zhi 2011, 14, 194-198. [PubMed]

38. Martinho, O.; Faloppa, C.C.; Neto, C.S.; Longatto-Filho, A.; Baiocchi, G.; da Cunha, I.W.; Soares, F.A.; Fregnani, J.H.T.G.; Reis, R.M. Loss of RKIP expression during the carcinogenic evolution of endometrial cancer. J. Clin. Pathol. 2012, 65, 122-128. [CrossRef] [PubMed]

39. Zaravinos, A.; Bizakis, J.; Spandidos, D.A. RKIP and BRAF aberrations in human nasal polyps and the adjacent turbinate mucosae. Cancer Lett. 2008, 264, 288-298. [CrossRef] [PubMed]

40. Lin, K.; Baritaki, S.; Militello, L.; Malaponte, G.; Bevelacqua, Y.; Bonavida, B. The Role of B-RAF Mutations in Melanoma and the Induction of EMT via Dysregulation of the NF- $k B /$ Snail/RKIP/PTEN Circuit. Genes Cancer 2010, 1, 409-420. [CrossRef] [PubMed]

41. Al-Mulla, F.; Hagan, S.; Al-Ali, W.; Jacob, S.P.; Behbehani, A.I.; Bitar, M.S.; Dallol, A.; Kolch, W. Raf kinase inhibitor protein: Mechanism of loss of expression and association with genomic instability. J. Clin. Pathol. 2008, 61, 524-529. [CrossRef] [PubMed]

42. Schuierer, M.M.; Bataille, F.; Weiss, T.S.; Hellerbrand, C.; Bosserhoff, A.K. Raf kinase inhibitor protein is downregulated in hepatocellular carcinoma. Oncol. Rep. 2006, 16, 451-456. [CrossRef] [PubMed]

43. Xu, Y.F.; Yi, Y.; Qiu, S.J.; Gao, Q.; Li, Y.W.; Dai, C.X.; Cai, M.Y.; Ju, M.J.; Zhou, J.; Zhang, B.H.; et al. PEBP1 downregulation is associated to poor prognosis in HCC related to hepatitis B infection. J. Hepatol. 2010, 53, 872-879. [CrossRef] [PubMed]

44. Zaravinos, A.; Chatziioannou, M.; Lambrou, G.I.; Boulalas, I.; Delakas, D.; Spandidos, D.A. Implication of RAF and RKIP genes in urinary bladder cancer. Pathol. Oncol. Res. 2011, 17, 181-190. [CrossRef] [PubMed]

45. Park, S.; Yeung, M.L.; Beach, S.; Shields, J.M.; Yeung, K.C. RKIP downregulates B-Raf kinase activity in melanoma cancer cells. Oncogene 2005, 24, 3535-3540. [CrossRef] [PubMed]

46. Chen, Y.; Ouyang, G.L.; Yi, H.; Li, M.Y.; Zhang, P.F.; Li, C.; Li, J.L.; Liu, Y.F.; Chen, Z.C.; Xiao, Z.Q. Identification of RKIP as an invasion suppressor protein in nasopharyngeal carcinoma by proteomic analysis. J. Proteome Res. 2008, 7, 5254-5262. [CrossRef] [PubMed]

47. Chen, Y.; Tang, C.E.; Ouyang, G.L.; Ruan, L.; Li, M.Y.; Zhang, P.F.; Li, C.; Yi, H.; Peng, F.; Li, J.L.; et al. Identification of RKIP as a differentially tyrosine-phosphorylated protein in nasopharyngeal carcinoma and normal nasopharyngeal epithelial tissues by phosphoproteomic approach. Med. Oncol. 2009, 26, 463-470. [CrossRef] [PubMed]

48. Gimenez, M.; Souza, V.C.; Izumi, C.; Barbieri, M.R.; Chammas, R.; Oba-Shinjo, S.M.; Uno, M.; Marie, S.K.N.; Rosa, J.C. Proteomic analysis of low- to high-grade astrocytomas reveals an alteration of the expression level of raf kinase inhibitor protein and nucleophosmin. Proteomics 2010, 10, 2812-2821. [CrossRef] [PubMed]

49. Wang, J.; Yang, Y.H.; Wang, A.Q.; Yao, B.; Xie, G.; Feng, G.; Zhang, Y.; Cheng, Z.S.; Hui, L.; Dai, T.Z.; et al. Immunohistochemical detection of the Raf kinase inhibitor protein in nonneoplastic gastric tissue and gastric cancer tissue. Med. Oncol. 2010, 27, 219-223. [CrossRef] [PubMed]

50. Kim, H.S.; Kim, G.Y.; Lim, S.J.; Kim, Y.W. Loss of Raf-1 kinase inhibitory protein in pancreatic ductal adenocarcinoma. Pathology 2010, 42, 655-660. [CrossRef] [PubMed] 
51. Kim, H.S.; Kim, G.Y.; Lim, S.J.; Kim, Y.W. Raf-1 kinase inhibitory protein expression in thyroid carcinomas. Endocr. Pathol. 2010, 21, 253-257. [CrossRef] [PubMed]

52. Lu, S.; Zhong, K.; Zhu, L.; He, L. Expression of Raf kinase inhibitor protein and E-cadherin in prostate cancer tissues. Zhong Nan Da Xue Xue Bao Yi Xue Ban 2009, 34, 892-897. [PubMed]

53. Birner, P.; Jesch, B.; Schultheis, A.; Schoppmann, S.F. RAF-kinase inhibitor protein (RKIP) downregulation in esophageal cancer and its metastases. Clin. Exp. Metastasis 2012, 29, 551-559. [CrossRef] [PubMed]

54. Zebisch, A.; Wölfler, A.; Fried, I.; Wolf, O.; Lind, K.; Bodner, C.; Haller, M.; Drasche, A.; Pirkebner, D.; Matallanas, D.; et al. Frequent loss of RAF kinase inhibitor protein expression in acute myeloid leukemia. Leukemia 2012, 26, 1842-1849. [CrossRef] [PubMed]

55. Zebisch, A.; Haller, M.; Hiden, K.; Goebel, T.; Hoefler, G.; Troppmair, J.; Sill, H. Loss of RAF kinase inhibitor protein is a somatic event in the pathogenesis of therapy-related acute myeloid leukemias with C-RAF germline mutations. Leukemia 2009, 23, 1049-1053. [CrossRef] [PubMed]

56. Takemura, T.; Nakamura, S.; Yokota, D.; Hirano, I.; Ono, T.; Shigeno, K.; Fujisawa, S.; Ohnishi, K. Reduction of Raf kinase inhibitor protein expression by Bcr-Abl contributes to chronic myelogenous leukemia proliferation. J. Biol. Chem. 2010, 285, 6585-6594. [CrossRef] [PubMed]

57. Jia, B.; Liu, H.; Kong, Q.; Li, B. RKIP expression associated with gastric cancer cell invasion and metastasis. Tumour Biol. 2012, 33, 919-925. [CrossRef] [PubMed]

58. Schuierer, M.M.; Bataille, F.; Hagan, S.; Kolch, W.; Bosserhoff, A.K. Reduction in Raf kinase inhibitor protein expression is associated with increased Ras-extracellular signal-regulated kinase signaling in melanoma cell lines. Cancer Res. 2004, 64, 5186-5192. [CrossRef] [PubMed]

59. Cheng, X.K.; Yu, G.Z.; Li, X.D.; Ren, X.Q. Molecular mechanism of hepatitis B virus (HBV) on suppression of raf kinase inhibitor protein (RKIP) expression. Oncotarget 2017, 8, 1132-1140. [CrossRef] [PubMed]

60. Kim, G.E.; Kim, N.I.; Lee, J.S.; Park, M.H.; Yoon, J.H. Reduced RKIP Expression is Associated with Breast Neoplastic Progression and is Correlated with Poor Outcomes and Aberrant Methylation in Breast Carcinoma. Appl. Immunohistochem. Mol. Morphol. 2017, 25, 467-474. [CrossRef] [PubMed]

61. Li, B.; Dewey, C.N. RSEM: Accurate transcript quantification from RNA-Seq data with or without a reference genome. BMC Bioinform. 2011, 12, 323. [CrossRef] [PubMed]

62. Ren, G.; Baritaki, S.; Marathe, H.; Feng, J.; Park, S.; Beach, S.; Bazeley, P.S.; Beshir, A.B.; Fenteany, G.; Mehra, R.; et al. Polycomb protein EZH2 regulates tumor invasion via the transcriptional repression of the metastasis suppressor RKIP in breast and prostate cancer. Cancer Res. 2012, 72, 3091-3104. [CrossRef] [PubMed]

63. Lee, J.; Lee, J.; Farquhar, K.S.; Yun, J.; Frankenberger, C.A.; Bevilacqua, E.; Yeung, K.; Kim, E.J.; Balázsi, G.; Rosner, M.R. Network of mutually repressive metastasis regulators can promote cell heterogeneity and metastatic transitions. Proc. Natl. Acad. Sci. USA 2014, 111, E364-E373. [CrossRef] [PubMed]

64. Zhang, B.; Wang, O.; Qin, J.; Liu, S.; Sun, S.; Liu, H.; Kuang, J.; Jiang, G.; Zhang, W. cis-Acting elements and trans-acting factors in the transcriptional regulation of raf kinase inhibitory protein expression. PLOS ONE 2013, 8, e83097. [CrossRef] [PubMed]

65. Zhang, H.; Wu, J.; Keller, J.M.; Yeung, K.; Keller, E.T.; Fu, Z. Transcriptional regulation of RKIP expression by androgen in prostate cells. Cell. Physiol. Biochem. 2012, 30, 1340-1350. [CrossRef] [PubMed]

66. Huang, L.; Dai, T.; Lin, X.; Zhao, X.; Chen, X.; Wang, C.; Li, X.; Shen, H.; Wang, X. MicroRNA-224 targets RKIP to control cell invasion and expression of metastasis genes in human breast cancer cells. Biochem. Biophys. Res. Commun. 2012, 425, 127-133. [CrossRef] [PubMed]

67. Du, Y.; Liu, X.H.; Zhu, H.C.; Wang, L.; Ning, J.Z.; Xiao, C.C. MiR-543 Promotes Proliferation and Epithelial-Mesenchymal Transition in Prostate Cancer via Targeting RKIP. Cell. Physiol. Biochem. 2017, 41, 1135-1146. [CrossRef] [PubMed]

68. Li, J.; Wang, Y.; Song, Y.; Fu, Z.; Yu, W. miR-27a regulates cisplatin resistance and metastasis by targeting RKIP in human lung adenocarcinoma cells. Mol. Cancer 2014, 13, 193. [CrossRef] [PubMed]

69. Hatzl, S.; Geiger, O.; Kuepper, M.K.; Caraffini, V.; Seime, T.; Furlan, T.; Nussbaumer, E.; Wieser, R.; Pichler, M.; Scheideler, M.; et al. Increased Expression of miR-23a Mediates a Loss of Expression in the RAF Kinase Inhibitor Protein RKIP. Cancer Res. 2016, 76, 3644-3654. [CrossRef] [PubMed]

70. Du, Y.; Weng, X.D.; Wang, L.; Liu, X.H.; Zhu, H.C.; Guo, J.; Ning, J.Z.; Xiao, C.C. LncRNA XIST acts as a tumor suppressor in prostate cancer through sponging miR-23a to modulate RKIP expression. Oncotarget 2017, 8, 94358-94370. [CrossRef] [PubMed] 
71. Ye, C.; Shen, Z.; Wang, B.; Li, Y.; Li, T.; Yang, Y.; Jiang, K.; Ye, Y.; Wang, S. A novel long non-coding RNA lnc-GNAT1-1 is low expressed in colorectal cancer and acts as a tumor suppressor through regulating RKIP-NF-kB-Snail circuit. J. Exp. Clin. Cancer Res. 2016, 35, 187. [CrossRef] [PubMed]

72. Li, H.; Ouyang, R.; Wang, Z.; Zhou, W.; Chen, H.; Jiang, Y.; Zhang, Y.; Li, H.; Liao, M.; Wang, W.; et al. MiR-150 promotes cellular metastasis in non-small cell lung cancer by targeting FOXO4. Sci. Rep. 2016, 6, 39001. [CrossRef] [PubMed]

73. Zaravinos, A.; Kanellou, P.; Lambrou, G.I.; Spandidos, D.A. Gene set enrichment analysis of the NF-кB/Snail/YY1/RKIP circuitry in multiple myeloma. Tumour Biol. 2014, 35, 4987-5005. [CrossRef] [PubMed]

74. Baritaki, S.; Militello, L.; Malaponte, G.; Spandidos, D.A.; Salcedo, M.; Bonavida, B. The anti-CD20 mAb LFB-R603 interrupts the dysregulated NF-kB/Snail/RKIP/PTEN resistance loop in B-NHL cells: Role in sensitization to TRAIL apoptosis. Int. J. Oncol. 2011, 38, 1683-1694. [PubMed]

75. Cross-Knorr, S.; Lu, S.; Perez, K.; Guevara, S.; Brilliant, K.; Pisano, C.; Quesenberry, P.J.; Resnick, M.B.; Chatterjee, D. RKIP phosphorylation and STAT3 activation is inhibited by oxaliplatin and camptothecin and are associated with poor prognosis in stage II colon cancer patients. BMC Cancer 2013, 13, 463. [CrossRef] [PubMed]

76. Nisimova, L.; Wen, S.; Cross-Knorr, S.; Rogers, A.B.; Moss, S.F.; Chatterjee, D. Role of Raf kinase inhibitor protein in Helicobacter pylori-mediated signaling in gastric cancer. Crit. Rev. Oncog. 2014, 19, 469-481. [CrossRef] [PubMed]

77. Kolch, W. Coordinating ERK/MAPK signalling through scaffolds and inhibitors. Nat. Rev. Mol. Cell Biol. 2005, 6, 827-837. [CrossRef] [PubMed]

78. Deiss, K.; Kisker, C.; Lohse, M.J.; Lorenz, K. Raf kinase inhibitor protein (RKIP) dimer formation controls its target switch from Raf1 to G protein-coupled receptor kinase (GRK) 2. J. Biol. Chem. 2012, 287, 23407-23417. [CrossRef] [PubMed]

79. Papale, M.; Vocino, G.; Lucarelli, G.; Rutigliano, M.; Gigante, M.; Rocchetti, M.T.; Pesce, F.; Sanguedolce, F.; Bufo, P.; Battaglia, M.; et al. Urinary RKIP/p-RKIP is a potential diagnostic and prognostic marker of clear cell renal cell carcinoma. Oncotarget 2017, 8, 40412-40424. [CrossRef] [PubMed]

80. Shvartsur, A.; Givechian, K.B.; Garban, H.; Bonavida, B. Overexpression of RKIP and its cross-talk with several regulatory gene products in multiple myeloma. J. Exp. Clin. Cancer Res. 2017, 36, 62. [CrossRef] [PubMed]

81. Keller, E.T. Metastasis suppressor genes: A role for raf kinase inhibitor protein (RKIP). Anticancer. Drugs 2004, 15, 663-669. [CrossRef] [PubMed]

82. Baritaki, S.; Huerta-Yepez, S.; Cabrava-Haimandez, M.d.L.; Sensi, M.; Canevari, S.; Libra, M.; Penichet, M.; Chen, H.; Berenson, J.R.; Bonavida, B. Unique Pattern of Overexpression of Raf-1 Kinase Inhibitory Protein in Its Inactivated Phosphorylated Form in Human Multiple Myeloma. For. Immunopathol. Dis. Therap. 2011, 2. [CrossRef] [PubMed]

83. Rajkumar, K.; Nichita, A.; Anoor, P.K.; Raju, S.; Singh, S.S.; Burgula, S. Understanding perspectives of signalling mechanisms regulating PEBP1 function. Cell Biochem. Funct. 2016, 34, 394-403. [CrossRef] [PubMed]

84. Dai, H.; Chen, H.; Liu, W.; You, Y.; Tan, J.; Yang, A.; Lai, X.; Bie, P. Effects of Raf kinase inhibitor protein expression on pancreatic cancer cell growth and motility: An in vivo and in vitro study. J. Cancer Res. Clin. Oncol. 2016, 142, 2107-2117. [CrossRef] [PubMed]

85. Yeung, K.; Janosch, P.; McFerran, B.; Rose, D.W.; Mischak, H.; Sedivy, J.M.; Kolch, W. Mechanism of suppression of the Raf/MEK/extracellular signal-regulated kinase pathway by the raf kinase inhibitor protein. Mol. Cell. Biol. 2000, 20, 3079-3085. [CrossRef] [PubMed]

86. Corbit, K.C.; Trakul, N.; Eves, E.M.; Diaz, B.; Marshall, M.; Rosner, M.R. Activation of Raf-1 signaling by protein kinase $C$ through a mechanism involving Raf kinase inhibitory protein. J. Biol. Chem. 2003, 278, 13061-13068. [CrossRef] [PubMed]

87. Granovsky, A.E.; Clark, M.C.; McElheny, D.; Heil, G.; Hong, J.; Liu, X.; Kim, Y.; Joachimiak, G.; Joachimiak, A.; Koide, S.; et al. Raf kinase inhibitory protein function is regulated via a flexible pocket and novel phosphorylation-dependent mechanism. Mol. Cell. Biol. 2009, 29, 1306-1320. [CrossRef] [PubMed] 
88. Skinner, J.J.; Wang, S.; Lee, J.; Ong, C.; Sommese, R.; Sivaramakrishnan, S.; Koelmel, W.; Hirschbeck, M.; Schindelin, H.; Kisker, C.; et al. Conserved salt-bridge competition triggered by phosphorylation regulates the protein interactome. Proc. Natl. Acad. Sci. USA 2017, 114, 13453-13458. [CrossRef] [PubMed]

89. Huang, S.; Pettaway, C.A.; Uehara, H.; Bucana, C.D.; Fidler, I.J. Blockade of NF-kappaB activity in human prostate cancer cells is associated with suppression of angiogenesis, invasion, and metastasis. Oncogene 2001, 20, 4188-4197. [CrossRef] [PubMed]

90. Pahl, H.L. Activators and target genes of Rel/NF-kappaB transcription factors. Oncogene 1999, 18, $6853-6866$. [CrossRef] [PubMed]

91. Shetty, S.; Graham, B.A.; Brown, J.G.; Hu, X.; Vegh-Yarema, N.; Harding, G.; Paul, J.T.; Gibson, S.B. Transcription factor NF-kappaB differentially regulates death receptor 5 expression involving histone deacetylase 1. Mol. Cell. Biol. 2005, 25, 5404-5416. [CrossRef] [PubMed]

92. Al-Mulla, F.; Bitar, M.S.; Al-Maghrebi, M.; Behbehani, A.I.; Al-Ali, W.; Rath, O.; Doyle, B.; Tan, K.Y.; Pitt, A.; Kolch, W. Raf kinase inhibitor protein RKIP enhances signaling by glycogen synthase kinase-3 $\beta$. Cancer Res. 2011, 71, 1334-1343. [CrossRef] [PubMed]

93. Xie, T.X.; Wei, D.; Liu, M.; Gao, A.C.; Ali-Osman, F.; Sawaya, R.; Huang, S. Stat3 activation regulates the expression of matrix metalloproteinase-2 and tumor invasion and metastasis. Oncogene 2004, 23, 3550-3560. [CrossRef] [PubMed]

94. Azare, J.; Leslie, K.; Al-Ahmadie, H.; Gerald, W.; Weinreb, P.H.; Violette, S.M.; Bromberg, J. Constitutively activated Stat 3 induces tumorigenesis and enhances cell motility of prostate epithelial cells through integrin beta 6. Mol. Cell. Biol. 2007, 27, 4444-4453. [CrossRef] [PubMed]

95. Dauer, D.J.; Ferraro, B.; Song, L.; Yu, B.; Mora, L.; Buettner, R.; Enkemann, S.; Jove, R.; Haura, E.B. Stat3 regulates genes common to both wound healing and cancer. Oncogene 2005, 24, 3397-3408. [CrossRef] [PubMed]

96. Buettner, R.; Mora, L.B.; Jove, R. Activated STAT signaling in human tumors provides novel molecular targets for therapeutic intervention. Clin. Cancer Res. 2002, 8, 945-954. [PubMed]

97. Yousuf, S.; Duan, M.; Moen, E.L.; Cross-Knorr, S.; Brilliant, K.; Bonavida, B.; LaValle, T.; Yeung, K.C.; Al-Mulla, F.; Chin, E.; et al. Raf kinase inhibitor protein (RKIP) blocks signal transducer and activator of transcription 3 (STAT3) activation in breast and prostate cancer. PLoS ONE 2014, 9, e92478. [CrossRef] [PubMed]

98. Zhang, X.M.; Zhou, C.; Gu, H.; Yan, L.; Zhang, G.Y. Correlation of RKIP, STAT3 and cyclin D1 expression in pathogenesis of gastric cancer. Int. J. Clin. Exp. Pathol. 2014, 7, 5902-5908. [PubMed]

99. Wang, A.; Duan, G.; Zhao, C.; Gao, Y.; Liu, X.; Wang, Z.; Li, W.; Wang, K.; Wang, W. Reduced RKIP expression levels are associated with frequent non-small cell lung cancer metastasis and STAT3 phosphorylation and activation. Oncol. Lett. 2017, 13, 3039-3045. [CrossRef] [PubMed]

100. Maresch, J.; Birner, P.; Zakharinov, M.; Toumangelova-Uzeir, K.; Natchev, S.; Guentchev, M. Additive effect on survival of Raf kinase inhibitor protein and signal transducer and activator of transcription 3 in high-grade glioma. Cancer 2011, 117, 2499-2504. [CrossRef] [PubMed]

101. Datar, I.; Qiu, X.; Ma, H.Z.; Yeung, M.; Aras, S.; de la Serna, I.; Al-Mulla, F.; Thiery, J.P.; Trumbly, R.; Fan, X.; et al. RKIP regulates CCL5 expression to inhibit breast cancer invasion and metastasis by controlling macrophage infiltration. Oncotarget 2015, 6, 39050-39061. [CrossRef] [PubMed]

102. Datar, I.; Feng, J.; Qiu, X.; Lewandowski, J.; Yeung, M.; Ren, G.; Aras, S.; Al-Mulla, F.; Cui, H.; Trumbly, R.; et al. RKIP Inhibits Local Breast Cancer Invasion by Antagonizing the Transcriptional Activation of MMP13. PLoS ONE 2015, 10, e0134494. [CrossRef] [PubMed]

103. Ankasha, S.J.; Shafiee, M.N.; Wahab, N.A.; Ali, R.A.R.; Mokhtar, N.M. Post-transcriptional regulation of microRNAs in cancer: From prediction to validation. Oncol. Rev. 2018, 12, 344. [CrossRef] [PubMed]

104. Johnson, S.M.; Grosshans, H.; Shingara, J.; Byrom, M.; Jarvis, R.; Cheng, A.; Labourier, E.; Reinert, K.L.; Brown, D.; Slack, F.J. RAS is regulated by the let-7 microRNA family. Cell 2005, 120, 635-647. [CrossRef] [PubMed]

105. Bevilacqua, E.; Frankenberger, C.A.; Rosner, M.R. RKIP Suppresses Breast Cancer Metastasis to the Bone by Regulating Stroma-Associated Genes. Int. J. Breast Cancer 2012, 2012, 124704. [CrossRef] [PubMed]

106. Yun, J.; Frankenberger, C.A.; Kuo, W.L.; Boelens, M.C.; Eves, E.M.; Cheng, N.; Liang, H.; Li, W.H.; Ishwaran, H.; Minn, A.J.; et al. Signalling pathway for RKIP and Let-7 regulates and predicts metastatic breast cancer. EMBO J. 2011, 30, 4500-4514. [CrossRef] [PubMed] 
107. Tavazoie, S.F.; Alarcón, C.; Oskarsson, T.; Padua, D.; Wang, Q.; Bos, P.D.; Gerald, W.L.; Massagué, J. Endogenous human microRNAs that suppress breast cancer metastasis. Nature 2008, 451, 147-152. [CrossRef] [PubMed]

108. Ma, L.; Teruya-Feldstein, J.; Weinberg, R.A. Tumour invasion and metastasis initiated by microRNA-10b in breast cancer. Nature 2007, 449, 682-688. [CrossRef] [PubMed]

109. Sun, M.; Gomes, S.; Chen, P.; Frankenberger, C.A.; Sankarasharma, D.; Chung, C.H.; Chada, K.K.; Rosner, M.R. RKIP and HMGA2 regulate breast tumor survival and metastasis through lysyl oxidase and syndecan-2. Oncogene 2014, 33, 3528-3537. [CrossRef] [PubMed]

110. Thuault, S.; Valcourt, U.; Petersen, M.; Manfioletti, G.; Heldin, C.H.; Moustakas, A. Transforming growth factor-beta employs HMGA2 to elicit epithelial-mesenchymal transition. J. Cell Biol. 2006, 174, 175-183. [CrossRef] [PubMed]

111. Davudian, S.; Mansoori, B.; Shajari, N.; Mohammadi, A.; Baradaran, B. BACH1, the master regulator gene: A novel candidate target for cancer therapy. Gene 2016, 588, 30-37. [CrossRef] [PubMed]

112. Sun, M.; Song, C.X.; Huang, H.; Frankenberger, C.A.; Sankarasharma, D.; Gomes, S.; Chen, P.; Chen, J.; Chada, K.K.; He, C.; et al. HMGA2/TET1/HOXA9 signaling pathway regulates breast cancer growth and metastasis. Proc. Natl. Acad. Sci. USA 2013, 110, 9920-9925. [CrossRef] [PubMed]

113. Peter, M.E. Let-7 and miR-200 microRNAs: Guardians against pluripotency and cancer progression. Cell Cycle 2009, 8, 843-852. [CrossRef] [PubMed]

114. Erler, J.T.; Bennewith, K.L.; Nicolau, M.; Dornhöfer, N.; Kong, C.; Le, Q.T.; Chi, J.T.A.; Jeffrey, S.S.; Giaccia, A.J. Lysyl oxidase is essential for hypoxia-induced metastasis. Nature 2006, 440, 1222-1226. [CrossRef] [PubMed]

115. Chen, Z.; Cheng, Q.; Ma, Z.; Xi, H.; Peng, R.; Jiang, B. Overexpression of RKIP inhibits cell invasion in glioma cell lines through upregulation of miR-98. Biomed. Res. Int. 2013, 2013, 695179. [CrossRef] [PubMed]

116. Zou, Q.; Wu, H.; Fu, F.; Yi, W.; Pei, L.; Zhou, M. RKIP suppresses the proliferation and metastasis of breast cancer cell lines through up-regulation of miR-185 targeting HMGA2. Arch. Biochem. Biophys. 2016, 610, 25-32. [CrossRef] [PubMed]

117. Forsythe, J.A.; Jiang, B.H.; Iyer, N.V.; Agani, F.; Leung, S.W.; Koos, R.D.; Semenza, G.L. Activation of vascular endothelial growth factor gene transcription by hypoxia-inducible factor 1. Mol. Cell. Biol. 1996, 16, 4604-4613. [CrossRef] [PubMed]

118. John, A.; Tuszynski, G. The role of matrix metalloproteinases in tumor angiogenesis and tumor metastasis. Pathol. Oncol. Res. 2001, 7, 14-23. [CrossRef] [PubMed]

119. Li, C.W.; Xia, W.; Huo, L.; Lim, S.O.; Wu, Y.; Hsu, J.L.; Chao, C.H.; Yamaguchi, H.; Yang, N.K.; Ding, Q.; et al. Epithelial-mesenchymal transition induced by TNF- $\alpha$ requires NF- $\kappa$ B-mediated transcriptional upregulation of Twist1. Cancer Res. 2012, 72, 1290-1300. [CrossRef] [PubMed]

120. Wu, Y.; Deng, J.; Rychahou, P.G.; Qiu, S.; Evers, B.M.; Zhou, B.P. Stabilization of snail by NF-kappaB is required for inflammation-induced cell migration and invasion. Cancer Cell 2009, 15, 416-428. [CrossRef] [PubMed]

121. Collins, T.; Read, M.A.; Neish, A.S.; Whitley, M.Z.; Thanos, D.; Maniatis, T. Transcriptional regulation of endothelial cell adhesion molecules: NF-kappa B and cytokine-inducible enhancers. FASEB J. 1995, 9, 899-909. [CrossRef] [PubMed]

122. Kang, Y.; Massagué, J. Epithelial-mesenchymal transitions: Twist in development and metastasis. Cell 2004, 118, 277-279. [CrossRef] [PubMed]

123. Bonavida, B.; Baritaki, S. Dual role of NO donors in the reversal of tumor cell resistance and EMT: Downregulation of the NF-kB/Snail/YY1/RKIP circuitry. Nitric Oxide Biol. Chem. 2011, 24, 1-7. [CrossRef] [PubMed]

124. Beshir, A.B.; Ren, G.; Magpusao, A.N.; Barone, L.M.; Yeung, K.C.; Fenteany, G. Raf kinase inhibitor protein suppresses nuclear factor- $\mathrm{kB}$-dependent cancer cell invasion through negative regulation of matrix metalloproteinase expression. Cancer Lett. 2010, 299, 137-149. [CrossRef] [PubMed]

125. Kim, S.O.; Kim, M.R. (-)-Epigallocatechin 3-gallate inhibits invasion by inducing the expression of Raf kinase inhibitor protein in AsPC-1 human pancreatic adenocarcinoma cells through the modulation of histone deacetylase activity. Int. J. Oncol. 2013, 42, 349-358. [CrossRef] [PubMed]

126. Zhu, C.X.; Li, W.Z.; Guo, Y.L.; Chen, L.; Li, G.H.; Yu, J.J.; Shu, B.; Peng, S. Tumor suppressor RKIP inhibits prostate cancer cell metastasis and sensitizes prostate cancer cells to docetaxel treatment. Neoplasma 2018, 65, 228-233. [CrossRef] [PubMed] 
127. Wu, X.; Yang, Y.; Xu, Z.; Li, J.; Yang, B.; Feng, N.; Zhang, Y.; Wang, S. Raf kinase inhibitor protein mediated signaling inhibits invasion and metastasis of hepatocellular carcinoma. Biochim. Biophys. Acta 2016, 1860, 384-391. [CrossRef] [PubMed]

128. Chen, T.C.; Hsu, Y.L.; Tsai, Y.C.; Chang, Y.W.; Kuo, P.L.; Chen, Y.H. Gemifloxacin inhibits migration and invasion and induces mesenchymal-epithelial transition in human breast adenocarcinoma cells. J. Mol. Med. 2014, 92, 53-64. [CrossRef] [PubMed]

129. Das, S.K.; Bhutia, S.K.; Sokhi, U.K.; Azab, B.; Su, Z.Z.; Boukerche, H.; Anwar, T.; Moen, E.L.; Chatterjee, D.; Pellecchia, M.; et al. Raf kinase inhibitor RKIP inhibits MDA-9/syntenin-mediated metastasis in melanoma. Cancer Res. 2012, 72, 6217-6226. [CrossRef] [PubMed]

130. Baritaki, S.; Chapman, A.; Yeung, K.; Spandidos, D.A.; Palladino, M.; Bonavida, B. Inhibition of epithelial to mesenchymal transition in metastatic prostate cancer cells by the novel proteasome inhibitor, NPI-0052: Pivotal roles of Snail repression and RKIP induction. Oncogene 2009, 28, 3573-3585. [CrossRef] [PubMed]

131. Baritaki, S.; Huerta-Yepez, S.; Sahakyan, A.; Karagiannides, I.; Bakirtzi, K.; Jazirehi, A.; Bonavida, B. Mechanisms of nitric oxide-mediated inhibition of EMT in cancer: Inhibition of the metastasis-inducer Snail and induction of the metastasis-suppressor RKIP. Cell Cycle 2010, 9, 4931-4940. [CrossRef] [PubMed]

132. Pires, B.R.B.; Mencalha, A.L.; Ferreira, G.M.; de Souza, W.F.; Morgado-Díaz, J.A.; Maia, A.M.; Corrêa, S.; Abdelhay, E.S.F.W. NF-kappaB Is Involved in the Regulation of EMT Genes in Breast Cancer Cells. PLoS ONE 2017, 12, e0169622. [CrossRef] [PubMed]

133. Tsubaki, M.; Komai, M.; Fujimoto, S.I.; Itoh, T.; Imano, M.; Sakamoto, K.; Shimaoka, H.; Takeda, T.; Ogawa, N.; Mashimo, K.; et al. Activation of NF- $\mathrm{kB}$ by the RANKL/RANK system up-regulates snail and twist expressions and induces epithelial-to-mesenchymal transition in mammary tumor cell lines. J. Exp. Clin. Cancer Res. 2013, 32, 62. [CrossRef] [PubMed]

134. Zhou, H.; Li, J.; Zhang, Z.; Ye, R.; Shao, N.; Cheang, T.; Wang, S. RING1 and YY1 binding protein suppresses breast cancer growth and metastasis. Int. J. Oncol. 2016, 49, 2442-2452. [CrossRef] [PubMed]

135. Wang, H.; Hertlein, E.; Bakkar, N.; Sun, H.; Acharyya, S.; Wang, J.; Carathers, M.; Davuluri, R.; Guttridge, D.C. NF-kappaB regulation of YY1 inhibits skeletal myogenesis through transcriptional silencing of myofibrillar genes. Mol. Cell. Biol. 2007, 27, 4374-4387. [CrossRef] [PubMed]

136. Palmer, M.B.; Majumder, P.; Cooper, J.C.; Yoon, H.; Wade, P.A.; Boss, J.M. Yin yang 1 regulates the expression of snail through a distal enhancer. Mol. Cancer Res. 2009, 7, 221-229. [CrossRef] [PubMed]

137. Bonavida, B.; Baritaki, S. The novel role of Yin Yang 1 in the regulation of epithelial to mesenchymal transition in cancer via the dysregulated NF-kB/Snail/YY1/RKIP/PTEN Circuitry. Crit. Rev. Oncog. 2011, 16, $211-226$. [CrossRef] [PubMed]

138. Bonavida, B.; Baritaki, S.; Huerta-Yepez, S.; Vega, M.I.; Chatterjee, D.; Yeung, K. Novel therapeutic applications of nitric oxide donors in cancer: Roles in chemo- and immunosensitization to apoptosis and inhibition of metastases. Nitric Oxide Biol. Chem. 2008, 19, 152-157. [CrossRef] [PubMed]

139. Martinez-Paniagua, M.A.; Vega, M.I.; Huerta-Yepez, S.; Baritaki, S.; Vega, G.G.; Hariharan, K.; Bonavida, B. Galiximab signals B-NHL cells and inhibits the activities of NF- $\mathrm{kB}$-induced YY1- and snail-resistant factors: Mechanism of sensitization to apoptosis by chemoimmunotherapeutic drugs. Mol. Cancer Ther. 2012, 11, 572-581. [CrossRef] [PubMed]

140. Lee, T.Y.; Liu, C.L.; Chang, Y.C.; Nieh, S.; Lin, Y.S.; Jao, S.W.; Chen, S.F.; Liu, T.Y. Increased chemoresistance via Snail-Raf kinase inhibitor protein signaling in colorectal cancer in response to a nicotine derivative. Oncotarget 2016, 7, 23512-23520. [CrossRef] [PubMed]

141. Finn, R.S. Targeting Src in breast cancer. Ann. Oncol. 2008, 19, 1379-1386. [CrossRef] [PubMed]

142. Yu, C.L.; Meyer, D.J.; Campbell, G.S.; Larner, A.C.; Carter-Su, C.; Schwartz, J.; Jove, R. Enhanced DNA-binding activity of a Stat3-related protein in cells transformed by the Src oncoprotein. Science 1995, 269, 81-83. [CrossRef] [PubMed]

143. Ng, D.C.H.; Lin, B.H.; Lim, C.P.; Huang, G.; Zhang, T.; Poli, V.; Cao, X. Stat3 regulates microtubules by antagonizing the depolymerization activity of stathmin. J. Cell Biol. 2006, 172, 245-257. [CrossRef] [PubMed]

144. Liu, S.; Li, X.; Lin, Z.; Su, L.; Yan, S.; Zhao, B.; Miao, J. SEC-induced activation of ANXA7 GTPase suppresses prostate cancer metastasis. Cancer Lett. 2018, 416, 11-23. [CrossRef] [PubMed]

145. He, Q.Y.; Yi, H.M.; Yi, H.; Xiao, T.; Qu, J.Q.; Yuan, L.; Zhu, J.F.; Li, J.Y.; Wang, Y.Y.; Li, L.N.; et al. Reduction of RKIP expression promotes nasopharyngeal carcinoma invasion and metastasis by activating Stat 3 signaling. Oncotarget 2015, 6, 16422-16436. [CrossRef] [PubMed] 
146. Egeblad, M.; Werb, Z. New functions for the matrix metalloproteinases in cancer progression. Nat. Rev. Cancer 2002, 2, 161-174. [CrossRef] [PubMed]

147. Zhao, D.; Ma, J.; Shi, J.; Cheng, L.; Li, F.; Jiang, X.; Jiang, H. Raf kinase inhibitor protein inhibits esophageal cancer cell invasion through downregulation of matrix metalloproteinase expression. Oncol. Rep. 2013, 30, 304-312. [CrossRef] [PubMed]

148. Bond, M.; Chase, A.J.; Baker, A.H.; Newby, A.C. Inhibition of transcription factor NF-kappaB reduces matrix metalloproteinase-1, -3 and -9 production by vascular smooth muscle cells. Cardiovasc. Res. 2001, 50, 556-565. [CrossRef]

149. Kim, D.; Kim, S.; Koh, H.; Yoon, S.O.; Chung, A.S.; Cho, K.S.; Chung, J. Akt/PKB promotes cancer cell invasion via increased motility and metalloproteinase production. FASEB J. 2001, 15, 1953-1962. [CrossRef] [PubMed]

150. Cui, C.; Shi, Q.; Zhang, X.; Liu, X.; Bai, Y.; Li, J.; Liu, S.; Hu, S.; Wei, Y. CRP promotes MMP-10 expression via c-Raf/MEK/ERK and JAK1/ERK pathways in cardiomyocytes. Cell. Signal. 2012, 24, 810-818. [CrossRef] [PubMed]

151. Shin, S.; Dimitri, C.A.; Yoon, S.O.; Dowdle, W.; Blenis, J. ERK2 but not ERK1 induces epithelial-to-mesenchymal transformation via DEF motif-dependent signaling events. Mol. Cell 2010, 38, 114-127. [CrossRef] [PubMed]

152. Lei, X.; Chang, L.; Ye, W.; Jiang, C.; Zhang, Z. Raf kinase inhibitor protein (RKIP) inhibits the cell migration and invasion in human glioma cell lines in vitro. Int. J. Clin. Exp. Pathol. 2015, 8, 14214-14220. [PubMed]

153. Noh, H.S.; Hah, Y.S.; Ha, J.H.; Kang, M.Y.; Zada, S.; Rha, S.Y.; Kang, S.S.; Kim, H.J.; Park, J.Y.; Byun, J.H.; et al. Regulation of the epithelial to mesenchymal transition and metastasis by Raf kinase inhibitory protein-dependent Notch1 activity. Oncotarget 2016, 7, 4632-4646. [CrossRef] [PubMed]

154. Nickoloff, B.J.; Osborne, B.A.; Miele, L. Notch signaling as a therapeutic target in cancer: A new approach to the development of cell fate modifying agents. Oncogene 2003, 22, 6598-6608. [CrossRef] [PubMed]

155. Shao, S.; Zhao, X.; Zhang, X.; Luo, M.; Zuo, X.; Huang, S.; Wang, Y.; Gu, S.; Zhao, X. Notch1 signaling regulates the epithelial-mesenchymal transition and invasion of breast cancer in a Slug-dependent manner. Mol. Cancer 2015, 14, 28. [CrossRef] [PubMed]

156. Wang, X.Q.; Zhang, W.; Lui, E.L.H.; Zhu, Y.; Lu, P.; Yu, X.; Sun, J.; Yang, S.; Poon, R.T.P.; Fan, S.T. Notch1-Snail1-E-cadherin pathway in metastatic hepatocellular carcinoma. Int. J. Cancer 2012, 131, E163-E172. [CrossRef] [PubMed]

157. Capaccione, K.M.; Pine, S.R. The Notch signaling pathway as a mediator of tumor survival. Carcinogenesis 2013, 34, 1420-1430. [CrossRef] [PubMed]

158. Ranganathan, P.; Weaver, K.L.; Capobianco, A.J. Notch signalling in solid tumours: A little bit of everything but not all the time. Nat. Rev. Cancer 2011, 11, 338-351. [CrossRef] [PubMed]

159. Wang, H.; Chen, L. Tumor microenviroment and hepatocellular carcinoma metastasis. J. Gastroenterol. Hepatol. 2013, 28 (Suppl. 1), 43-48. [CrossRef]

160. Frankenberger, C.; Rabe, D.; Bainer, R.; Sankarasharma, D.; Chada, K.; Krausz, T.; Gilad, Y.; Becker, L.; Rosner, M.R. Metastasis Suppressors Regulate the Tumor Microenvironment by Blocking Recruitment of Prometastatic Tumor-Associated Macrophages. Cancer Res. 2015, 75, 4063-4073. [CrossRef] [PubMed]

161. Roufas, C.; Chasiotis, D.; Makris, A.; Efstathiades, C.; Dimopoulos, C.; Zaravinos, A. The Expression and Prognostic Impact of Immune Cytolytic Activity-Related Markers in Human Malignancies: A Comprehensive Meta-analysis. Front. Oncol. 2018, 8, 27. [CrossRef] [PubMed]

162. Buschow, S.I.; Ramazzotti, M.; Reinieren-Beeren, I.M.J.; Heinzerling, L.M.; Westdorp, H.; Stefanini, I.; Beltrame, L.; Hato, S.V.; Ellebaek, E.; Gross, S.; et al. Survival of metastatic melanoma patients after dendritic cell vaccination correlates with expression of leukocyte phosphatidylethanolamine-binding protein $1 /$ Raf kinase inhibitory protein. Oncotarget 2017, 8, 67439-67456. [CrossRef] [PubMed]

163. Wei, H.; Gao, H.Q.; Li, H.B.; Qi, S.J.; Liu, W.L.; Xu, L.; Li, H.; Liu, J.X.; Dong, Z.M. Correlation among RKIP expression, NF-kB p65 levels, and T-lymphocyte subsets in gastric cardia adenocarcinoma. Genet. Mol. Res. 2015, 14, 16491-16496. [CrossRef] [PubMed]

164. Ruan, L.; Wang, G.L.; Yi, H.; Chen, Y.; Tang, C.E.; Zhang, P.F.; Li, M.Y.; Li, C.; Peng, F.; Li, J.L.; et al. Raf kinase inhibitor protein correlates with sensitivity of nasopharyngeal carcinoma to radiotherapy. J. Cell. Biochem. 2010, 110, 975-981. [CrossRef] [PubMed]

165. Baritaki, S.; Bonavida, B. Viral infection and cancer: The NF-kappaB/Snail/RKIP loop regulates target cell sensitivity to apoptosis by cytotoxic lymphocytes. Crit. Rev. Immunol. 2010, 30, 31-46. [CrossRef] [PubMed] 
166. Lee, J.Y.; Huerta-Yepez, S.; Vega, M.; Baritaki, S.; Spandidos, D.A.; Bonavida, B. The NO TRAIL to YES TRAIL in cancer therapy (review). Int. J. Oncol. 2007, 31, 685-691. [CrossRef] [PubMed]

167. Bai, M.; Ma, X.; Li, X.; Wang, X.; Mei, Q.; Li, X.; Wu, Z.; Han, W. The Accomplices of NF-kB Lead to Radioresistance. Curr. Protein Pept. Sci. 2015, 16, 279-294. [CrossRef] [PubMed]

168. Xie, S.Y.; Li, G.; Han, C.; Yu, Y.Y.; Li, N. RKIP reduction enhances radioresistance by activating the Shh signaling pathway in non-small-cell lung cancer. Oncol. Targets Ther. 2017, 10, 5605-5619. [CrossRef] [PubMed]

169. Bai, X.Y.; Zhang, X.C.; Yang, S.Q.; An, S.J.; Chen, Z.H.; Su, J.; Xie, Z.; Gou, L.Y.; Wu, Y.L. Blockade of Hedgehog Signaling Synergistically Increases Sensitivity to Epidermal Growth Factor Receptor Tyrosine Kinase Inhibitors in Non-Small-Cell Lung Cancer Cell Lines. PLoS ONE 2016, 11, e0149370. [CrossRef] [PubMed]

170. Heiden, K.B.; Williamson, A.J.; Doscas, M.E.; Ye, J.; Wang, Y.; Liu, D.; Xing, M.; Prinz, R.A.; Xu, X. The sonic hedgehog signaling pathway maintains the cancer stem cell self-renewal of anaplastic thyroid cancer by inducing snail expression. J. Clin. Endocrinol. Metab. 2014, 99, E2178-E2187. [CrossRef] [PubMed]

171. Huerta-Yepez, S.; Liu, H.; Baritaki, S.; Del Lourdes Cebrera-Muñoz, M.; Rivera-Pazos, C.; Maldonado-Valenzuela, A.; Valencia-Hipolito, A.; Vega, M.I.; Chen, H.; Berenson, J.R.; et al. Overexpression of Yin Yang 1 in bone marrow-derived human multiple myeloma and its clinical significance. Int. J. Oncol. 2014, 45, 1184-1192. [CrossRef] [PubMed]

172. Huerta-Yepez, S.; Baritaki, S.; Baay-Guzman, G.; Hernandez-Luna, M.A.; Hernandez-Cueto, A.; Vega, M.I.; Bonavida, B. Contribution of either YY1 or BclXL-induced inhibition by the NO-donor DETANONOate in the reversal of drug resistance, both in vitro and in vivo. YY1 and BclXL are overexpressed in prostate cancer. Nitric Oxide Biol. Chem. 2013, 29, 17-24. [CrossRef] [PubMed]

173. Baritaki, S.; Huerta-Yepez, S.; Sakai, T.; Spandidos, D.A.; Bonavida, B. Chemotherapeutic drugs sensitize cancer cells to TRAIL-mediated apoptosis: Up-regulation of DR5 and inhibition of Yin Yang 1. Mol. Cancer Ther. 2007, 6, 1387-1399. [CrossRef] [PubMed]

174. Castellano, G.; Torrisi, E.; Ligresti, G.; Malaponte, G.; Militello, L.; Russo, A.E.; McCubrey, J.A.; Canevari, S.; Libra, M. The involvement of the transcription factor Yin Yang 1 in cancer development and progression. Cell Cycle 2009, 8, 1367-1372. [CrossRef] [PubMed]

175. Bonavida, B. Regulation of Cell Death Apoptotic Pathways by Nitric Oxide in Cancer: Reversal of Drug/Immune Resistance. Redox Biol. 2015, 5, 415. [CrossRef] [PubMed]

176. Rapozzi, V.; Varchi, G.; Della Pietra, E.; Ferroni, C.; Xodo, L.E. A photodynamic bifunctional conjugate for prostate cancer: An in vitro mechanistic study. Investig. New Drugs 2017, 35, 115-123. [CrossRef] [PubMed]

177. Rapozzi, V.; Della Pietra, E.; Bonavida, B. Dual roles of nitric oxide in the regulation of tumor cell response and resistance to photodynamic therapy. Redox Biol. 2015, 6, 311-317. [CrossRef] [PubMed]

178. Garbán, H.J.; Bonavida, B. Nitric oxide inhibits the transcription repressor Yin-Yang 1 binding activity at the silencer region of the Fas promoter: A pivotal role for nitric oxide in the up-regulation of Fas gene expression in human tumor cells. J. Immunol. 2001, 167, 75-81. [CrossRef] [PubMed]

179. Sisto, M.; Lisi, S.; D'Amore, M.; Lofrumento, D.D. Rituximab-mediated Raf kinase inhibitor protein induction modulates NF-кB in Sjögren syndrome. Immunology 2014, 143, 42-51. [CrossRef] [PubMed]

180. Bonavida, B. Rituximab-induced inhibition of antiapoptotic cell survival pathways: Implications in chemo/immunoresistance, rituximab unresponsiveness, prognostic and novel therapeutic interventions. Oncogene 2007, 26, 3629-3636. [CrossRef] [PubMed]

181. Huerta-Yepez, S.; Vega, M.; Garban, H.; Bonavida, B. Involvement of the TNF-alpha autocrine-paracrine loop, via NF-kappaB and YY1, in the regulation of tumor cell resistance to Fas-induced apoptosis. Clin. Immunol. 2006, 120, 297-309. [CrossRef] [PubMed]

182. Huerta-Yepez, S.; Vega, M.; Escoto-Chavez, S.E.; Murdock, B.; Sakai, T.; Baritaki, S.; Bonavida, B. Nitric oxide sensitizes tumor cells to TRAIL-induced apoptosis via inhibition of the DR5 transcription repressor Yin Yang 1. Nitric Oxide Biol. Chem. 2009, 20, 39-52. [CrossRef] [PubMed]

183. Vega, M.I.; Huerta-Yepez, S.; Jazirehi, A.R.; Garban, H.; Bonavida, B. Rituximab (chimeric anti-CD20) sensitizes B-NHL cell lines to Fas-induced apoptosis. Oncogene 2005, 24, 8114-8127. [CrossRef] [PubMed] 
184. Martínez-Paniagua, M.A.; Baritaki, S.; Huerta-Yepez, S.; Ortiz-Navarrete, V.F.; González-Bonilla, C.; Bonavida, B.; Vega, M.I. Mcl-1 and YY1 inhibition and induction of DR5 by the BH3-mimetic Obatoclax (GX15-070) contribute in the sensitization of B-NHL cells to TRAIL apoptosis. Cell Cycle 2011, 10, 2792-2805. [CrossRef] [PubMed]

185. Garbán, H.J.; Bonavida, B. Nitric oxide sensitizes ovarian tumor cells to Fas-induced apoptosis. Gynecol. Oncol. 1999, 73, 257-264. [CrossRef] [PubMed]

186. Reséndiz-Martínez, J.; Asbun-Bojalil, J.; Huerta-Yepez, S.; Vega, M. Correlation of the expression of YY1 and Fas cell surface death receptor with apoptosis of peripheral blood mononuclear cells, and the development of multiple organ dysfunction in children with sepsis. Mol. Med. Rep. 2017, 15, 2433-2442. [CrossRef] [PubMed]

187. Hernandez-Cueto, A.; Hernandez-Cueto, D.; Antonio-Andres, G.; Mendoza-Marin, M.; Jimenez-Gutierrez, C.; Sandoval-Mejia, A.L.; Mora-Campos, R.; Gonzalez-Bonilla, C.; Vega, M.I.; Bonavida, B.; et al. Death receptor 5 expression is inversely correlated with prostate cancer progression. Mol. Med. Rep. 2014, 10, 2279-2286. [CrossRef] [PubMed]

188. Vega, M.I.; Martínez-Paniagua, M.; Huerta-Yepez, S.; González-Bonilla, C.; Uematsu, N.; Bonavida, B. Dysregulation of the cell survival/anti-apoptotic NF-kappaB pathway by the novel humanized BM-ca anti-CD20 mAb: Implication in chemosensitization. Int. J. Oncol. 2009, 35, 1289-1296. [CrossRef] [PubMed]

189. Vega, M.I.; Baritaki, S.; Huerta-Yepez, S.; Martinez-Paniagua, M.A.; Bonavida, B. A potential mechanism of rituximab-induced inhibition of tumor growth through its sensitization to tumor necrosis factor-related apoptosis-inducing ligand-expressing host cytotoxic cells. Leuk. Lymphoma 2011, 52, 108-121. [CrossRef] [PubMed]

190. Miltenberger, R.J.; Farnham, P.J.; Smith, D.E.; Stommel, J.M.; Cornwell, M.M. v-Raf activates transcription of growth-responsive promoters via GC-rich sequences that bind the transcription factor Sp1. Cell Growth Differ. 1995, 6, 549-556. [PubMed]

191. Kim, S.H.; Lee, S.H.; Kwak, N.H.; Kang, C.D.; Chung, B.S. Effect of the activated Raf protein kinase on the human multidrug resistance 1 (MDR1) gene promoter. Cancer Lett. 1996, 98, 199-205. [CrossRef]

192. Blagosklonny, M.V. Drug-resistance enables selective killing of resistant leukemia cells: Exploiting of drug resistance instead of reversal. Leukemia 1999, 13, 2031-2035. [CrossRef] [PubMed]

193. Blagosklonny, M.V.; Schulte, T.; Nguyen, P.; Trepel, J.; Neckers, L.M. Taxol-induced apoptosis and phosphorylation of Bcl-2 protein involves c-Raf-1 and represents a novel c-Raf-1 signal transduction pathway. Cancer Res. 1996, 56, 1851-1854. [PubMed]

194. Weinstein-Oppenheimer, C.R.; Henríquez-Roldán, C.F.; Davis, J.M.; Navolanic, P.M.; Saleh, O.A.; Steelman, L.S.; Franklin, R.A.; Robinson, P.J.; McMahon, M.; McCubrey, J.A. Role of the Raf signal transduction cascade in the in vitro resistance to the anticancer drug doxorubicin. Clin. Cancer Res. 2001, 7, 2898-2907. [PubMed]

195. Davis, J.M.; Navolanic, P.M.; Weinstein-Oppenheimer, C.R.; Steelman, L.S.; Hu, W.; Konopleva, M.; Blagosklonny, M.V.; McCubrey, J.A. Raf-1 and Bcl-2 induce distinct and common pathways that contribute to breast cancer drug resistance. Clin. Cancer Res. 2003, 9, 1161-1170. [PubMed]

196. Weston, C.R.; Balmanno, K.; Chalmers, C.; Hadfield, K.; Molton, S.A.; Ley, R.; Wagner, E.F.; Cook, S.J. Activation of ERK1/2 by deltaRaf-1:ER* represses Bim expression independently of the JNK or PI3K pathways. Oncogene 2003, 22, 1281-1293. [CrossRef] [PubMed]

197. Ley, R.; Balmanno, K.; Hadfield, K.; Weston, C.; Cook, S.J. Activation of the ERK1/2 signaling pathway promotes phosphorylation and proteasome-dependent degradation of the BH3-only protein, Bim. J. Biol. Chem. 2003, 278, 18811-18816. [CrossRef] [PubMed]

198. Harada, H.; Quearry, B.; Ruiz-Vela, A.; Korsmeyer, S.J. Survival factor-induced extracellular signal-regulated kinase phosphorylates BIM, inhibiting its association with BAX and proapoptotic activity. Proc. Natl. Acad. Sci. USA 2004, 101, 15313-15317. [CrossRef] [PubMed]

199. Danielsen, S.A.; Eide, P.W.; Nesbakken, A.; Guren, T.; Leithe, E.; Lothe, R.A. Portrait of the PI3K/AKT pathway in colorectal cancer. Biochim. Biophys. Acta 2015, 1855, 104-121. [CrossRef] [PubMed]

200. Kim, J.S.; Choi, G.H.; Jung, Y.; Kim, K.M.; Jang, S.J.; Yu, E.S.; Lee, H.C. Downregulation of Raf-1 kinase inhibitory protein as a sorafenib resistance mechanism in hepatocellular carcinoma cell lines. J. Cancer Res. Clin. Oncol. 2018, 144, 1487-1501. [CrossRef] [PubMed] 
201. Yuan, L.; Yi, H.M.; Yi, H.; Qu, J.Q.; Zhu, J.F.; Li, L.N.; Xiao, T.; Zheng, Z.; Lu, S.-S.; Xiao, Z.Q. Reduced RKIP enhances nasopharyngeal carcinoma radioresistance by increasing ERK and AKT activity. Oncotarget 2016, 7, 11463-11477. [CrossRef] [PubMed]

202. Nie, F.; Cao, J.; Tong, J.; Zhu, M.; Gao, Y.; Ran, Z. Role of Raf-kinase inhibitor protein in colorectal cancer and its regulation by hydroxycamptothecine. J. Biomed. Sci. 2015, 22, 56. [CrossRef] [PubMed]

203. Zheng, H.C. The molecular mechanisms of chemoresistance in cancers. Oncotarget 2017, 8, 59950-59964. [CrossRef] [PubMed]

204. Dent, P.; Yacoub, A.; Contessa, J.; Caron, R.; Amorino, G.; Valerie, K.; Hagan, M.P.; Grant, S.; Schmidt-Ullrich, R. Stress and radiation-induced activation of multiple intracellular signaling pathways. Radiat. Res. 2003, 159, 283-300. [CrossRef]

205. Datta, S.R.; Dudek, H.; Tao, X.; Masters, S.; Fu, H.; Gotoh, Y.; Greenberg, M.E. Akt phosphorylation of BAD couples survival signals to the cell-intrinsic death machinery. Cell 1997, 91, 231-241. [CrossRef]

206. Cardone, M.H.; Roy, N.; Stennicke, H.R.; Salvesen, G.S.; Franke, T.F.; Stanbridge, E.; Frisch, S.; Reed, J.C. Regulation of cell death protease caspase-9 by phosphorylation. Science 1998, 282, 1318-1321. [CrossRef] [PubMed]

207. Steelman, L.S.; Chappell, W.H.; Abrams, S.L.; Kempf, R.C.; Long, J.; Laidler, P.; Mijatovic, S.; Maksimovic-Ivanic, D.; Stivala, F.; Mazzarino, M.C.; et al. Roles of the Raf/MEK/ERK and $\mathrm{PI} 3 \mathrm{~K} / \mathrm{PTEN} / \mathrm{Akt} / \mathrm{mTOR}$ pathways in controlling growth and sensitivity to therapy-implications for cancer and aging. Aging 2011, 3, 192-222. [CrossRef] [PubMed]

208. Mendoza, M.C.; Er, E.E.; Blenis, J. The Ras-ERK and PI3K-mTOR pathways: Cross-talk and compensation. Trends Biochem. Sci. 2011, 36, 320-328. [CrossRef] [PubMed]

209. Vivanco, I.; Sawyers, C.L. The phosphatidylinositol 3-Kinase AKT pathway in human cancer. Nat. Rev. Cancer 2002, 2, 489-501. [CrossRef] [PubMed]

210. Sebolt-Leopold, J.S.; Herrera, R. Targeting the mitogen-activated protein kinase cascade to treat cancer. Nat. Rev. Cancer 2004, 4, 937-947. [CrossRef] [PubMed]

211. Merighi, S.; Benini, A.; Mirandola, P.; Gessi, S.; Varani, K.; Leung, E.; Maclennan, S.; Baraldi, P.G.; Borea, P.A. Modulation of the Akt/Ras/Raf/MEK/ERK pathway by $\mathrm{A}_{3}$ adenosine receptor. Purinergic Signal. 2006, 2, 627-632. [CrossRef] [PubMed]

212. Moelling, K.; Schad, K.; Bosse, M.; Zimmermann, S.; Schweneker, M. Regulation of Raf-Akt Cross-talk. J. Biol. Chem. 2002, 277, 31099-31106. [CrossRef] [PubMed]

213. Murga, C.; Laguinge, L.; Wetzker, R.; Cuadrado, A.; Gutkind, J.S. Activation of Akt/protein kinase B by $\mathrm{G}$ protein-coupled receptors. A role for alpha and beta gamma subunits of heterotrimeric $\mathrm{G}$ proteins acting through phosphatidylinositol-3-OH kinasegamma. J. Biol. Chem. 1998, 273, 19080-19085. [CrossRef] [PubMed]

214. Kim, D.H.; Suh, J.; Surh, Y.J.; Na, H.K. Regulation of the tumor suppressor PTEN by natural anticancer compounds. Ann. N. Y. Acad. Sci. 2017, 1401, 136-149. [CrossRef] [PubMed]

215. Lin, Y.; Kang, T.; Zhou, B.P. Doxorubicin enhances Snail/LSD1-mediated PTEN suppression in a PARP1-dependent manner. Cell Cycle 2014, 13, 1708-1716. [CrossRef] [PubMed]

216. Karni, R.; Jove, R.; Levitzki, A. Inhibition of pp60c-Src reduces Bcl-XL expression and reverses the transformed phenotype of cells overexpressing EGF and HER-2 receptors. Oncogene 1999, 18, 4654-4662. [CrossRef] [PubMed]

217. Puthier, D.; Bataille, R.; Amiot, M. IL-6 up-regulates mcl-1 in human myeloma cells through JAK/STAT rather than ras/MAP kinase pathway. Eur. J. Immunol. 1999, 29, 3945-3950. [CrossRef]

218. Martinho, O.; Simões, K.; Longatto-Filho, A.; Jacob, C.E.; Zilberstein, B.; Bresciani, C.; Gama-Rodrigues, J.; Cecconello, I.; Alves, V.; Reis, R.M. Absence of RKIP expression is an independent prognostic biomarker for gastric cancer patients. Oncol. Rep. 2013, 29, 690-696. [CrossRef] [PubMed]

219. Zeng, L.; Imamoto, A.; Rosner, M.R. Raf kinase inhibitory protein (RKIP): A physiological regulator and future therapeutic target. Expert Opin. Ther. Targets 2008, 12, 1275-1287. [CrossRef] [PubMed]

220. Yu, M.; Wang, Q.; Ding, J.W.; Yang, Z.; Xie, C.; Lu, N.H. Association between raf kinase inhibitor protein loss and prognosis in cancers of the digestive system: A meta-analysis. Cancer Biomark. 2014, 14, 389-400. [CrossRef] [PubMed] 
221. Koelzer, V.H.; Karamitopoulou, E.; Dawson, H.; Kondi-Pafiti, A.; Zlobec, I.; Lugli, A. Geographic analysis of RKIP expression and its clinical relevance in colorectal cancer. Br. J. Cancer 2013, 108, 2088-2096. [CrossRef] [PubMed]

222. Gao, C.; Pang, L.; Ren, C.; Ma, T. Prognostic value of raf kinase inhibitor protein in esophageal squamous cell carcinoma. Pathol. Oncol. Res. 2012, 18, 471-477. [CrossRef] [PubMed]

223. Huang, Q.; Wei, L.; Liang, C.; Nie, J.; Lu, S.; Lu, C.; Tan, S.; Lv, S.; Zhuo, L.; Lu, Z.; et al. Loss of Raf kinase inhibitor protein is associated with malignant progression in hepatic fibrosis. Biomed. Pharmacother. 2016, 82, 669-676. [CrossRef] [PubMed]

224. Fujimori, Y.; Inokuchi, M.; Takagi, Y.; Kato, K.; Kojima, K.; Sugihara, K. Prognostic value of RKIP and p-ERK in gastric cancer. J. Exp. Clin. Cancer Res. 2012, 31, 30. [CrossRef] [PubMed]

225. Chatterjee, D.; Sabo, E.; Tavares, R.; Resnick, M.B. Inverse association between Raf Kinase Inhibitory Protein and signal transducers and activators of transcription 3 expression in gastric adenocarcinoma patients: Implications for clinical outcome. Clin. Cancer Res. 2008, 14, 2994-3001. [CrossRef] [PubMed]

226. Wu, X.; Wang, S.; Yang, Y.; Li, J.; Xu, Z.; Tang, R. Expression of Raf kinase inhibitor protein and its significance in invasion and metastasis of hepatocellular carcinoma. Zhonghua Zhong Liu Za Zhi 2011, 33, 358-362. [PubMed]

227. Kim, H.S.; Park, S.J.; Lee, K.Y.; Park, Y.K.; Kim, Y.W. Reduced Raf-1 kinase inhibitor protein expression predicts less favorable outcomes in patients with hepatic colorectal metastasis. Oncol. Rep. 2012, 28, 161-171. [CrossRef] [PubMed]

228. Moon, A.; Park, J.Y.; Sung, J.Y.; Park, Y.K.; Kim, Y.W. Reduced expression of Raf-1 kinase inhibitory protein in renal cell carcinoma: A significant prognostic marker. Pathology 2012, 44, 534-539. [CrossRef] [PubMed]

229. Bainer, R.; Frankenberger, C.; Rabe, D.; An, G.; Gilad, Y.; Rosner, M.R. Gene expression in local stroma reflects breast tumor states and predicts patient outcome. Sci. Rep. 2016, 6, 39240. [CrossRef] [PubMed]

230. Li, H.Z.; Wang, Y.; Gao, Y.; Shao, J.; Zhao, X.L.; Deng, W.M.; Liu, Y.X.; Yang, J.; Yao, Z. Effects of raf kinase inhibitor protein expression on metastasis and progression of human epithelial ovarian cancer. Mol. Cancer Res. 2008, 6, 917-928. [CrossRef] [PubMed]

231. Zlobec, I.; Baker, K.; Minoo, P.; Jass, J.R.; Terracciano, L.; Lugli, A. Node-negative colorectal cancer at high risk of distant metastasis identified by combined analysis of lymph node status, vascular invasion, and Raf-1 kinase inhibitor protein expression. Clin. Cancer Res. 2008, 14, 143-148. [CrossRef] [PubMed]

232. Karamitopoulou, E.; Zlobec, I.; Gloor, B.; Kondi-Pafiti, A.; Lugli, A.; Perren, A. Loss of Raf-1 kinase inhibitor protein (RKIP) is strongly associated with high-grade tumor budding and correlates with an aggressive phenotype in pancreatic ductal adenocarcinoma (PDAC). J. Transl. Med. 2013, 11, 311. [CrossRef] [PubMed]

233. Wei, H.; Liu, Z.; She, H.; Liu, B.; Gu, J.; Wei, D.; Zhang, X.; Wang, J.; Qi, S.; Ping, F. Promoter methylation and expression of Raf kinase inhibitory protein in esophageal squamous cell carcinoma. Oncol. Lett. 2017, 13, 1866-1872. [CrossRef] [PubMed]

234. Huerta-Yepez, S.; Yoon, N.K.; Hernandez-Cueto, A.; Mah, V.; Rivera-Pazos, C.M.; Chatterjee, D.; Vega, M.I.; Maresh, E.L.; Horvath, S.; Chia, D.; et al. Expression of phosphorylated raf kinase inhibitor protein (pRKIP) is a predictor of lung cancer survival. BMC Cancer 2011, 11, 259. [CrossRef] [PubMed]

235. Doyle, B.; Hagan, S.; Al-Mulla, F.; Scott, L.; Harden, S.; Paul, J.; Mulcahy, H.; Murray, G.I.; Sheahan, K.; O'Sullivan, J.; et al. Raf kinase inhibitor protein expression combined with peritoneal involvement and lymphovascular invasion predicts prognosis in Dukes' B colorectal cancer patients. Histopathology 2013, 62, 505-510. [CrossRef] [PubMed]

236. Al-Mulla, F.; Bitar, M.S.; Thiery, J.P.; Zea, T.T.; Chatterjee, D.; Bennett, L.; Park, S.; Edwards, J.; Yeung, K.C. Clinical implications for loss or diminution of expression of Raf- 1 kinase inhibitory protein and its phosphorylated form in ductal breast cancer. Am. J. Cancer Res. 2013, 3, 446-464. [PubMed]

237. Koelzer, V.H.; Lugli, A. The tumor border configuration of colorectal cancer as a histomorphological prognostic indicator. Front. Oncol. 2014, 4, 29. [CrossRef] [PubMed]

238. Ueno, H.; Hase, K.; Hashiguchi, Y.; Ishiguro, M.; Kajiwara, Y.; Shimazaki, H.; Mochizuki, H. Growth pattern in the muscular layer reflects the biological behaviour of colorectal cancer. Colorectal Dis. 2009, 11, 951-959. [CrossRef] [PubMed]

239. García-Solano, J.; Conesa-Zamora, P.; Trujillo-Santos, J.; Mäkinen, M.J.; Pérez-Guillermo, M. Tumour budding and other prognostic pathological features at invasive margins in serrated colorectal adenocarcinoma: A comparative study with conventional carcinoma. Histopathology 2011, 59, 1046-1056. [CrossRef] [PubMed] 
240. Jazirehi, A.R.; Bonavida, B. Cellular and molecular signal transduction pathways modulated by rituximab (rituxan, anti-CD20 mAb) in non-Hodgkin's lymphoma: Implications in chemosensitization and therapeutic intervention. Oncogene 2005, 24, 2121-2143. [CrossRef] [PubMed]

241. Hu, C.J.; Zhou, L.; Cai, Y. Dihydroartemisinin induces apoptosis of cervical cancer cells via upregulation of RKIP and downregulation of bcl-2. Cancer Biol. Ther. 2014, 15, 279-288. [CrossRef] [PubMed]

242. Singhal, J.; Nagaprashantha, L.D.; Vatsyayan, R.; Ashutosh; Awasthi, S.; Singhal, S.S. Didymin induces apoptosis by inhibiting N-Myc and upregulating RKIP in neuroblastoma. Cancer Prev. Res. 2012, 5, 473-483. [CrossRef] [PubMed]

243. Hsu, Y.L.; Chen, C.Y.; Lin, I.P.; Tsai, E.M.; Kuo, P.L.; Hou, M.F. 4-Shogaol, an active constituent of dietary ginger, inhibits metastasis of MDA-MB-231 human breast adenocarcinoma cells by decreasing the repression of NF-kB/Snail on RKIP. J. Agric. Food Chem. 2012, 60, 852-861. [CrossRef] [PubMed]

244. King, M.L.; Murphy, L.L. American ginseng (Panax quinquefolius L.) extract alters mitogen-activated protein kinase cell signaling and inhibits proliferation of MCF-7 cells. J. Exp. Ther. Oncol. 2007, 6, 147-155. [PubMed]

245. Labbozzetta, M.; Poma, P.; Vivona, N.; Gulino, A.; D'Alessandro, N.; Notarbartolo, M. Epigenetic changes and nuclear factor- $\mathrm{kB}$ activation, but not microRNA-224, downregulate Raf-1 kinase inhibitor protein in triple-negative breast cancer SUM 159 cells. Oncol. Lett. 2015, 10, 3807-3815. [CrossRef] [PubMed]

(c) 2018 by the authors. Licensee MDPI, Basel, Switzerland. This article is an open access article distributed under the terms and conditions of the Creative Commons Attribution (CC BY) license (http://creativecommons.org/licenses/by/4.0/). 